\begin{tabular}{|c|cc|c|}
\hline & PORT SAID ENGINEERING RESEARCH JOURNAL & Port Said University - Faculty of Engineering \\
\hline
\end{tabular}

\title{
Effect of Cementitious Materials Composition on Heat Evolution and Strength of Concrete
}

\author{
Mohammed H. Belal ${ }^{1}$, Shady R. Ragheb ${ }^{2}$ and Hassan M. Hassan ${ }^{3}$
}

Received: 21 March 2020; Accepted: 1 July 2020

\begin{abstract}
Large and massive concrete structures with high cementitious content like foundations, tunnels, bridges, dams and hydraulic structures are subjected to cracks generated and developed by internal thermal stresses and damages due to delayed ettringite formation (DEF) associated with the hydration process of cement. The Ondes bridge, Bourgogne bridge and Saint-Maurice de Beynost bridge are international examples of concrete structures damaged by delayed ettringite formation. Due to the construction expansion in Egypt and the Middle East, it was necessary to study the effect of concrete constituents on the evolution of concrete heat of hydration and the differential temperature between the core and the concrete surface, as well as the mechanical properties such as the compressive strength. In this study, the effects of six types of cement, two water-binder ratios, with two different cement contents and supplementary cementitious materials like silica fume, fly ash and metakaolin were studied. The test results of hardened concrete showed that the blast-furnace cement and moderate heat of hydration cement had an obvious effect on the hydration heat rate and concrete compressive strength compared to other tested types. Partial replacement of cement by $50 \%$ fly ash led to a decrease in maximum hydration temperature nearly by $13-14 \%$. Replacement of cement by $15 \%$ metakaolin led to an increase in maximum temperature by $2.9 \%$ comparing to reference cement. A best thermal gradient of mass concrete was observed in case of using moderate heat of hydration cement, as the maximum temperature difference was $17.5^{\circ} \mathrm{C}$.
\end{abstract}

KEYWORDS: Hydration Heat; Cementitious Materials; Semi Adiabatic; Mass Concrete; Differential Temperature.

\section{INTRODUCTION}

Hydration of cement is an exothermic response and raises the interior temperature to a significant level [1]. The heat generated due to hydration of cement may cause early age strain aggregation inside concrete adding to splits or displacements [3]. Hydration process depends on many variables like, chemical composition and physical properties of cement, water/cement ratio (w/c), supplementary cementitious materials (SCMs), chemical admixtures, curing conditions and aggregate type [12]. Each chemical compound of cement shows a different hydration rate, the high rate of heat evolution in the early life of concrete can be decreased by reducing the proportions of the compounds that hydrate most rapidly $\left(\mathrm{C}_{3} \mathrm{~A}\right.$ and $\left.\mathrm{C}_{3} \mathrm{~S}\right)$ [6,10]. Increasing of sulfate content as $\left(\mathrm{SO}_{3}\right)$ reduces the heat of hydration because alumina is less soluble in a lime gypsum solution [12]. Water to cement mass ratio affects the early age thermal properties of cement pastes, as diminishing w/c will build the pinnacle temperature accomplished during semi adiabatic hydration [13]. Curing temperature affects hydration heat,

${ }^{I}$ Civil Engineering Department, Faculty of Engineering, Damietta, Egypt, corresponding author, email: mohammed_belal@du.edu.eg

${ }^{2}$ Civil Engineering Department, Faculty of Engineering, Port Said,Egypt,email: Shadyragheb@hotmail.com

${ }^{3}$ Civil Engineering Department, Faculty of Engineering, Port Said, Egypt, email: hassan_ghattass@eng.psu.edu.eg as a lower curing temperature moderated hydration [2]. Supplementary cementitious materials such as pozzolanic materials normally display slow hydration, accompanied by low temperature [15]. The heat of hydration can be determined according to (ASTM C 186 - 15a), but as of late, the calorimeter test techniques with observing warmth of hydration over time are all the more normally utilized [5,12]. Calorimetry tests can be arranged into three kinds: adiabatic, semi-adiabatic and isothermal calorimetry [19].

The hydration heat generated by cementitious materials in massive concrete may results in thermal cracks as it increases the temperature in the center of mass concrete in which the warm state is almost adiabatic. Whereas, the loss of warmth close to the surface to the surrounding climate is simpler [17].

The temperatures inside mass concrete may reach high levels, which may lead to deterioration as a result of delayed ettringite formation. The primary revealed instances of delayed ettringite formation happened in some precast concrete elements subjected to inappropriate heat treatment [8]. In massive concrete structure, greatest allowable concrete temperatures and temperature differences are regularly determined to ensure that proper planning happens before concrete placement. A large portion of the massive concrete specifications limit the allowable extreme temperature after placement to about $70{ }^{\circ} \mathrm{C}[1]$ and the maximum temperature difference to be in the range of $19{ }^{\circ} \mathrm{C}$ to $20^{\circ} \mathrm{C}[1,16,18]$. 
Several options are available to predict maximum concrete temperatures like PCA method. It is suitable for concrete containing somewhere in the range of 300 and $600 \mathrm{~kg}$ of cement per cubic meter of concrete and accept that minimal component of the solid part is in any event $1.8 \mathrm{~m}$ and it gives no data on time of most extreme temperature and does not permit the measurement of temperature differences $[16,18]$. Amore precise method for estimating maximum temperature and maximum temperature differences was developed by E. Schmidt and summarized in ACI 207.1R [16,20].

The effect of binder materials available in Egypt on the hydration heat needs to be studied, so the relevance of the research were to know the effect of cement type, water to binder ratio, cement content and partial replacement of cement by supplementary cementitious materials on the hydration heat evolution and compressive strength of concrete mixtures in order to find out the best types of cement used in terms of the lowest heat of hydration generated and best compressive strength, as well as investigate the effect of different types of cement on mass concrete hardening temperature development and thermal gradient, also determine the effect of thermal insulation on the distribution of heat inside concrete in order to avoid problems associated with the hydration process.
Six types of cement which produced according to British standard (BS EN197-1:2011) [11], Egyptian standard (ES 4756-1 - 2013) [7] and (ASTM C150 2012) [9] were used in the study: Ordinary Portland cement [CEM I (42.5 N)] as a reference cement, SulfateResistant cement [CEM I - SRC (42.5 N)], Moderate Heat of Hydration cement [Type II (MH)], PortlandPozzolan cements [CEM II /A, B - P (42.5 N)] and BlastFurnace cement [CEM III / A (42.5 N)]. [CEM I] was provided by El Arish Cement company, Al-Arish, North Sinai, [CEM I - SRC] was provided by Amreyah Cement company, Kilo 55, Matrouh North Coast Road, [Type II $(\mathrm{MH})]$ and [CEM II /A, B - P] were provided by Assiut Cement Company, Km. 18 Assiut/El-Wadi El-Gedid Road, Assiut and [CEM III / A] was provided by Suez Cement Company, Suez Plant, El-Ain El-Sokhna, Egypt.

Supplementary cementitious materials like fly ash, silica fume and metakaolin were added as a partial replacement of the cement to investigate their impact on the hydration heat evolution. Fly ash was provided by Geos Company, Cairo and silica fume was provided by Sika Egypt Company, Elobour, Egypt. The chemical composition of all cementitious materials was determined by X-ray fluorescence (XRF) method. The chemical and mineral compositions of all cementitious materials are shown in Tables (1) and (2) respectively.

\section{EXPERIMENTAL PROGRAM}

\subsection{Raw Materials}

Table 1: Chemical compositions of used cementitious materials

\begin{tabular}{|c|c|c|c|c|c|c|c|c|c|}
\hline \multirow[b]{2}{*}{ Oxide } & \multicolumn{9}{|c|}{ Cementitious material } \\
\hline & $\begin{array}{c}\text { CEM I } \\
(42.5 \mathrm{~N})\end{array}$ & $\begin{array}{c}\text { CEM I } \\
- \text { SRC } \\
(42.5 \mathrm{~N})\end{array}$ & $\begin{array}{l}\text { CEM II } \\
\text { / A - P } \\
(42.5 \mathrm{~N})\end{array}$ & $\begin{array}{c}\text { CEM II } \\
\text { / B - P } \\
(42.5 \mathrm{~N})\end{array}$ & $\begin{array}{c}\text { Type II } \\
\text { (MH) }\end{array}$ & $\begin{array}{c}\text { CEM } \\
\text { III / A } \\
(42.5 \mathrm{~N})\end{array}$ & $\begin{array}{c}\text { Fly } \\
\text { Ash } \\
\text { (FA) }\end{array}$ & $\begin{array}{r}\text { Silica } \\
\text { Fume } \\
\text { (SF) }\end{array}$ & $\begin{array}{c}\text { Metakaolin } \\
\text { (MK) }\end{array}$ \\
\hline $\mathrm{SiO}_{2} \%$ & 19.54 & 20.21 & 19.86 & 20.33 & 20.29 & 24.25 & 64.10 & 95.50 & 56.30 \\
\hline $\mathrm{Al}_{2} \mathrm{O}_{3} \%$ & 4.62 & 4.30 & 3.82 & 4.46 & 3.71 & 8.52 & 30.20 & 0.41 & 35.10 \\
\hline $\mathrm{Fe}_{2} \mathrm{O}_{3} \%$ & 3.36 & 6.25 & 4.74 & 5.96 & 4.94 & 2.35 & 1.42 & 0.47 & 1.54 \\
\hline $\mathrm{CaO} \%$ & 63.52 & 60.53 & 62.48 & 60.61 & 62.47 & 51.37 & 0.93 & 0.20 & 0.74 \\
\hline MgO\% & 1.28 & 2.62 & 1.65 & 2.71 & 1.69 & 5.60 & 0.85 & 0.69 & 0.69 \\
\hline $\mathrm{SO}_{3} \%$ & 2.15 & 2.32 & 2.10 & 2.34 & 1.94 & 2.71 & 0.24 & 0.16 & 0.48 \\
\hline L.O.I\% & 4.60 & 2.33 & 3.90 & 2.17 & 3.41 & 2.99 & 0.28 & 1.71 & 3.09 \\
\hline $\mathrm{Na}_{2} \mathrm{O} \%$ & 0.27 & 0.47 & 0.28 & 0.47 & 0.33 & 0.13 & 0.38 & 0.51 & 0.56 \\
\hline $\mathrm{K}_{2} \mathrm{O} \%$ & 0.13 & 0.20 & 0.17 & 0.19 & 0.17 & 0.44 & 0.47 & 0.18 & 0.08 \\
\hline $\mathrm{TiO}_{2} \%$ & 0.26 & 0.39 & 0.44 & 0.39 & 0.46 & 0.61 & 0.75 & - & 1.11 \\
\hline $\mathrm{P}_{2} \mathrm{O}_{5} \%$ & 0.12 & 0.10 & 0.23 & 0.10 & 0.21 & 0.07 & 0.22 & 0.03 & 0.17 \\
\hline $\mathrm{Mn}_{2} \mathrm{O}_{3} \%$ & 0.07 & 0.15 & 0.26 & 0.15 & 0.30 & 0.89 & - & - & - \\
\hline Ins.Res\% & 0.56 & 0.58 & 0.56 & 0.56 & 0.52 & 0.58 & - & - & - \\
\hline $\mathrm{Cl}^{\circ} \%$ & 0.05 & - & 0.04 & 0.06 & 0.04 & 0.06 & 0.02 & 0.06 & 0.05 \\
\hline $\mathrm{Na}_{2} \mathrm{O}$ Eq.\% & 0.36 & - & 0.39 & 0.60 & 0.44 & 0.43 & - & - & - \\
\hline LSF\% & 0.99 & 0.90 & 0.96 & 0.89 & 0.95 & 0.62 & - & - & - \\
\hline
\end{tabular}


Table 2: Mineral compositions of used cement (Bogue formula: ASTM C150 - 2016 [4])

\begin{tabular}{|c|c|c|c|c|}
\hline \multirow{2}{*}{ Cement type } & \multicolumn{4}{|c|}{ Mineral compositions wt. \% } \\
\hline & $\mathrm{C}_{3} \mathrm{~S}$ & $\mathrm{C}_{2} \mathrm{~S}$ & $\mathrm{C}_{3} \mathrm{~A}$ & $\mathrm{C}_{4} \mathrm{AF}$ \\
\hline $\begin{array}{c}\text { CEM I } \\
(42.5 \mathrm{~N})\end{array}$ & 68.11 & 4.64 & $\begin{array}{c}6.56 \\
(6.57)^{*}\end{array}$ & 10.22 \\
\hline $\begin{array}{c}\text { CEM I - SRC } \\
(42.5 \mathrm{~N})\end{array}$ & 48.38 & 21.44 & $\begin{array}{c}0.82 \\
(0.84)^{*}\end{array}$ & 19.02 \\
\hline $\begin{array}{c}\text { CEM II / A - } \\
\text { P } \\
(42.5 \mathrm{~N})\end{array}$ & 64.99 & 7.91 & $\begin{array}{c}2.10 \\
(2.12)^{*}\end{array}$ & 14.42 \\
\hline $\begin{array}{c}\text { CEM II / B - } \\
\text { P } \\
(42.5 \mathrm{~N}) \\
\end{array}$ & 47.08 & 22.77 & $\begin{array}{c}1.73 \\
(1.75)^{*}\end{array}$ & 18.14 \\
\hline $\begin{array}{c}\text { Type II } \\
(\mathrm{MH})(42.5 \mathrm{~N})\end{array}$ & 63.23 & 10.47 & $\begin{array}{c}2.23 \\
(1.5)^{*}\end{array}$ & 13.66 \\
\hline $\begin{array}{c}\text { CEM III / A } \\
(42.5 \text { N) }\end{array}$ & - & - & - & - \\
\hline
\end{tabular}

( )* From X-ray analysis.

Aggregates used in the study were natural sand as fine aggregate and the coarse aggregate used was crushed stone (1) and crushed stone (2). The mixing ratio of coarse aggregate was 2:3. Table (3) shows the physical properties of the aggregates used and Figures (1-3) show the grading curves of aggregates with the Egyptian Standard Specifications limits (ESS 1109/2009) [14].

Table 3: Physical properties of aggregate

\begin{tabular}{|c|c|c|c|}
\hline Aggregate type & $\begin{array}{c}\text { Fine } \\
\text { aggregate }\end{array}$ & $\begin{array}{c}\text { Crushed } \\
\text { Stone (1) }\end{array}$ & $\begin{array}{c}\text { Crushed } \\
\text { Stone (2) }\end{array}$ \\
\hline $\begin{array}{c}\text { Specific } \\
\text { gravity }\end{array}$ & 2.63 & 2.73 & 2.5 \\
\hline $\begin{array}{c}\text { Unit weight } \\
\left(\mathbf{t} / \mathbf{m}^{3}\right)\end{array}$ & 1.767 & 1.59 & 1.51 \\
\hline $\begin{array}{c}\text { Fineness } \\
\text { modulus }\end{array}$ & 2 & 6.1 & 6.53 \\
\hline $\begin{array}{c}\text { Percentage of } \\
\text { absorption (by } \\
\text { weight) }\end{array}$ & $0.5 \%$ & $1.2 \%$ & $1 \%$ \\
\hline $\begin{array}{c}\text { Nominal } \\
\text { maximum size }\end{array}$ & - & \multicolumn{2}{|c|}{20} \\
\hline
\end{tabular}

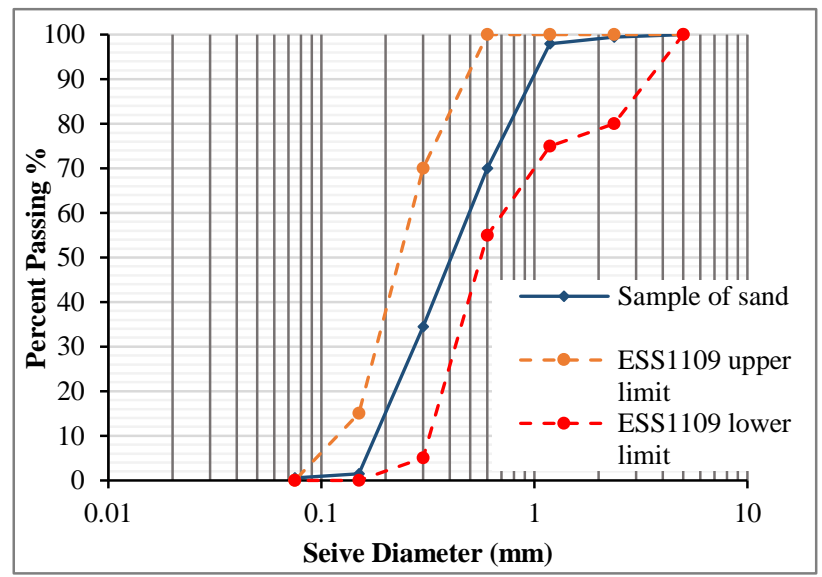

Figure 1: Grading curve of fine aggregate and ESS1109 limits

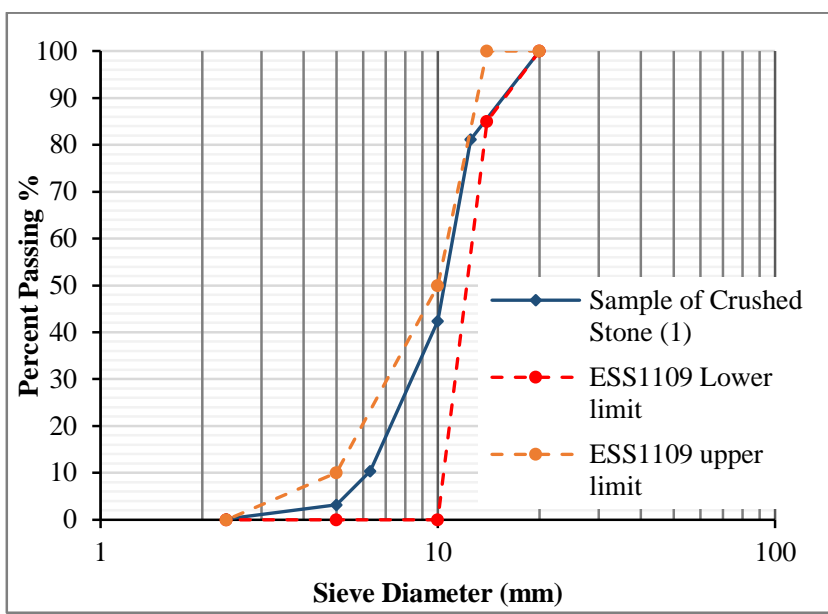

Figure 2: Grading curve of crushed stone (1) and ESS1109 limits

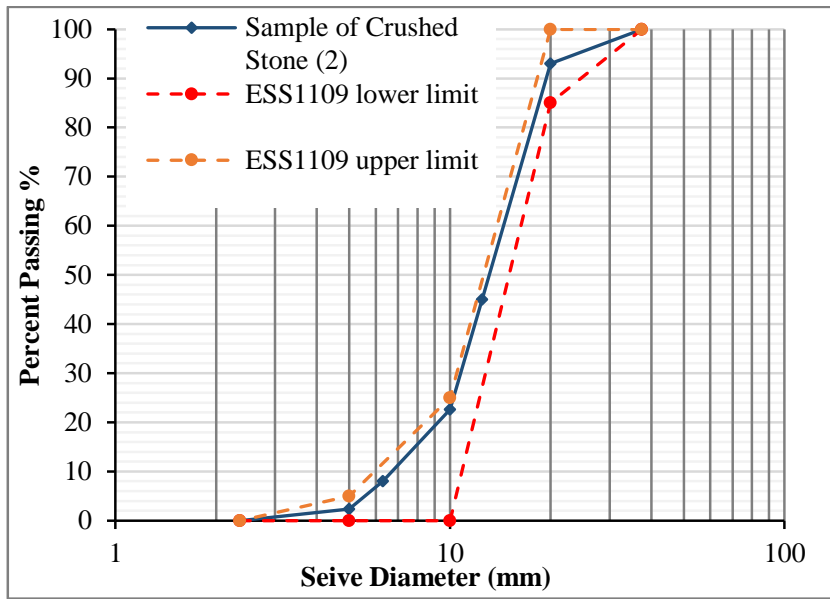

Figure 3: Grading curve of crushed stone (2) and ESS1109 limits

\subsection{Concrete Mix Proportion}

The concrete was designed with two different total cementitious materials content 450 and $350 \mathrm{~kg} / \mathrm{m}^{3}$ and with two different water to binder $(\mathrm{w} / \mathrm{b})$ ratios 0.4 and 0.5 . Fly ash, silica fume and metakaolin were used as supplementary cementitious materials. Replacement levels for supplementary cementitious materials (SCMs) were $30 \%$ and $50 \%$ for fly ash, $10 \%$ for silica fume and $10 \%$ and $15 \%$ for metakaolin. Many trials were done to determine the optimum dosage of the superplasticizer for each mixture. The concrete mixtures were divided into three phases (phase (1): with total cementitious materials content $450 \mathrm{~kg} / \mathrm{m}^{3}$ and $\mathrm{w} / \mathrm{b} 0.5$, phase (2): with total cementitious materials content $450 \mathrm{~kg} / \mathrm{m}^{3}$ and w/b 0.4 and phase (3): with total cementitious materials content 350 $\mathrm{kg} / \mathrm{m}^{3}$ and $\mathrm{w} / \mathrm{b} 0.4$ ). Table (4) summarizes the used mix proportions of concrete mixture.

\subsection{Concrete Specimens}

The size of concrete specimens for different experiments is shown in Table (5). 
Table 4: Mix proportions of concrete

\begin{tabular}{|c|c|c|c|c|c|}
\hline \multirow{2}{*}{\multicolumn{3}{|c|}{ Constituent }} & \multicolumn{3}{|c|}{ Content $\left(\mathrm{kg} / \mathrm{m}^{3}\right)$} \\
\hline & & & \multirow{2}{*}{$\begin{array}{c}\text { Phase } \\
\text { (1) } \\
450\end{array}$} & \multirow{2}{*}{$\begin{array}{c}\begin{array}{c}\text { Phase } \\
\text { (2) }\end{array} \\
450\end{array}$} & \multirow{2}{*}{$\begin{array}{c}\begin{array}{c}\text { Phase } \\
\text { (3) }\end{array} \\
350\end{array}$} \\
\hline \multirow{6}{*}{ 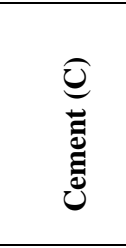 } & \multicolumn{2}{|c|}{ C - only } & & & \\
\hline & \multicolumn{2}{|c|}{$\mathrm{C}+30 \% \mathrm{FA}$} & 315 & 315 & - \\
\hline & \multicolumn{2}{|c|}{$\mathrm{C}+50 \% \mathrm{FA}$} & 225 & 225 & - \\
\hline & \multicolumn{2}{|c|}{$\mathrm{C}+10 \% \mathrm{SF}$} & 405 & 405 & - \\
\hline & \multicolumn{2}{|c|}{$\mathrm{C}+10 \% \mathrm{MK}$} & 405 & 405 & - \\
\hline & \multicolumn{2}{|c|}{$\mathrm{C}+15 \% \mathrm{MK}$} & 382.5 & - & - \\
\hline \multicolumn{3}{|c|}{ Water } & 225 & 180 & 140 \\
\hline \multirow{6}{*}{ 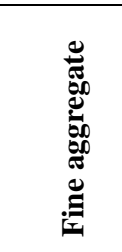 } & \multicolumn{2}{|c|}{ C - only } & 513.8 & 552.9 & 615.1 \\
\hline & \multicolumn{2}{|c|}{$\mathrm{C}+30 \% \mathrm{FA}$} & 502.2 & 541.2 & - \\
\hline & \multicolumn{2}{|c|}{$\mathrm{C}+50 \% \mathrm{FA}$} & 494.4 & 533.5 & - \\
\hline & \multicolumn{2}{|c|}{$\mathrm{C}+10 \% \mathrm{SF}$} & 509.9 & 549 & - \\
\hline & \multicolumn{2}{|c|}{$\mathrm{C}+10 \% \mathrm{MK}$} & 510.6 & 549.6 & - \\
\hline & \multicolumn{2}{|c|}{$\mathrm{C}+15 \% \mathrm{MK}$} & 509 & - & - \\
\hline \multirow{6}{*}{ 莺 } & \multicolumn{2}{|c|}{ C - only } & 1027.6 & 1105.7 & 1230.2 \\
\hline & \multicolumn{2}{|c|}{$\mathrm{C}+30 \% \mathrm{FA}$} & 1004.4 & 1082.5 & - \\
\hline & \multicolumn{2}{|c|}{$\mathrm{C}+50 \% \mathrm{FA}$} & 988.9 & 1067 & - \\
\hline & \multicolumn{2}{|c|}{$\mathrm{C}+10 \% \mathrm{SF}$} & 1019.9 & 1098 & - \\
\hline & \multicolumn{2}{|c|}{$\mathrm{C}+10 \% \mathrm{MK}$} & 1021.2 & 1099.3 & - \\
\hline & \multicolumn{2}{|c|}{$\mathrm{C}+15 \% \mathrm{MK}$} & 1018 & - & - \\
\hline \multirow{2}{*}{$\begin{array}{l}\text { Fly ash } \\
\text { (FA) }\end{array}$} & \multicolumn{2}{|c|}{$30 \%$} & 135 & 135 & - \\
\hline & \multicolumn{2}{|c|}{$50 \%$} & 225 & 225 & - \\
\hline \multicolumn{3}{|c|}{ Silica fume (SF) $10 \%$} & 45 & 45 & - \\
\hline \multirow{2}{*}{\multicolumn{2}{|c|}{$\begin{array}{l}\text { Metakaolin } \\
\text { (MK) }\end{array}$}} & $10 \%$ & 45 & 45 & - \\
\hline & & $15 \%$ & 67.5 & - & - \\
\hline annol & tis & $\begin{array}{l}\text { C - } \\
\text { only }\end{array}$ & 1.8 & 6.75 & 5.25 \\
\hline superpla & dicizer & $\begin{array}{c}\mathrm{C}+ \\
\mathrm{SCMs}\end{array}$ & 1.35 & 2.7 & - \\
\hline
\end{tabular}

Table 5: Size of concrete specimens

\begin{tabular}{|c|c|c|}
\hline Experiment & $\begin{array}{c}\text { Specimen } \\
\text { shape }\end{array}$ & $\begin{array}{c}\text { Specimen size } \\
\text { (cm) }\end{array}$ \\
\hline $\begin{array}{c}\text { Heat evolution } \\
\text { in concrete }\end{array}$ & prism & $15 \times 15 \times 30$ \\
\hline $\begin{array}{c}\text { Heat evolution } \\
\text { in mass } \\
\text { concrete }\end{array}$ & cube & $100 \times 100 \times$ \\
100
\end{tabular}

\subsection{Test Techniques and Measurements}

\subsubsection{Properties of Fresh Concrete}

Workability and density for fresh concrete were measured by slump test and unit weight test according to (ASTM C 143/C 143M - 15) and (ASTM C 138/C 138M $-14)$ respectively after the completion of mixing.

\subsubsection{Heat Evolution of Concrete}

The heat evolution in concrete due to cement hydration was measured in laboratory by the semi adiabatic test on a prismatic sample $(15 \mathrm{~cm} \times 15 \mathrm{~cm} \times 30 \mathrm{~cm})$ which was thermally insulated by extruded polystyrene foam with thickness of $10 \mathrm{~cm}$ from all directions and the inner sides of the foam were covered with a plastic bag (Thick nylon) to prevent any water absorption and leakage of concrete. Setup for semi adiabatic test is shown in Figure (4). For heat evolution measurements, a program was created by Arduino to record the readings and Type K Thermocouple (Nickel-Chromium / Nickel-Alumel) was used and connected to the Arduino. The readings were recorded every five minutes and continued for four days after casting the test sample.

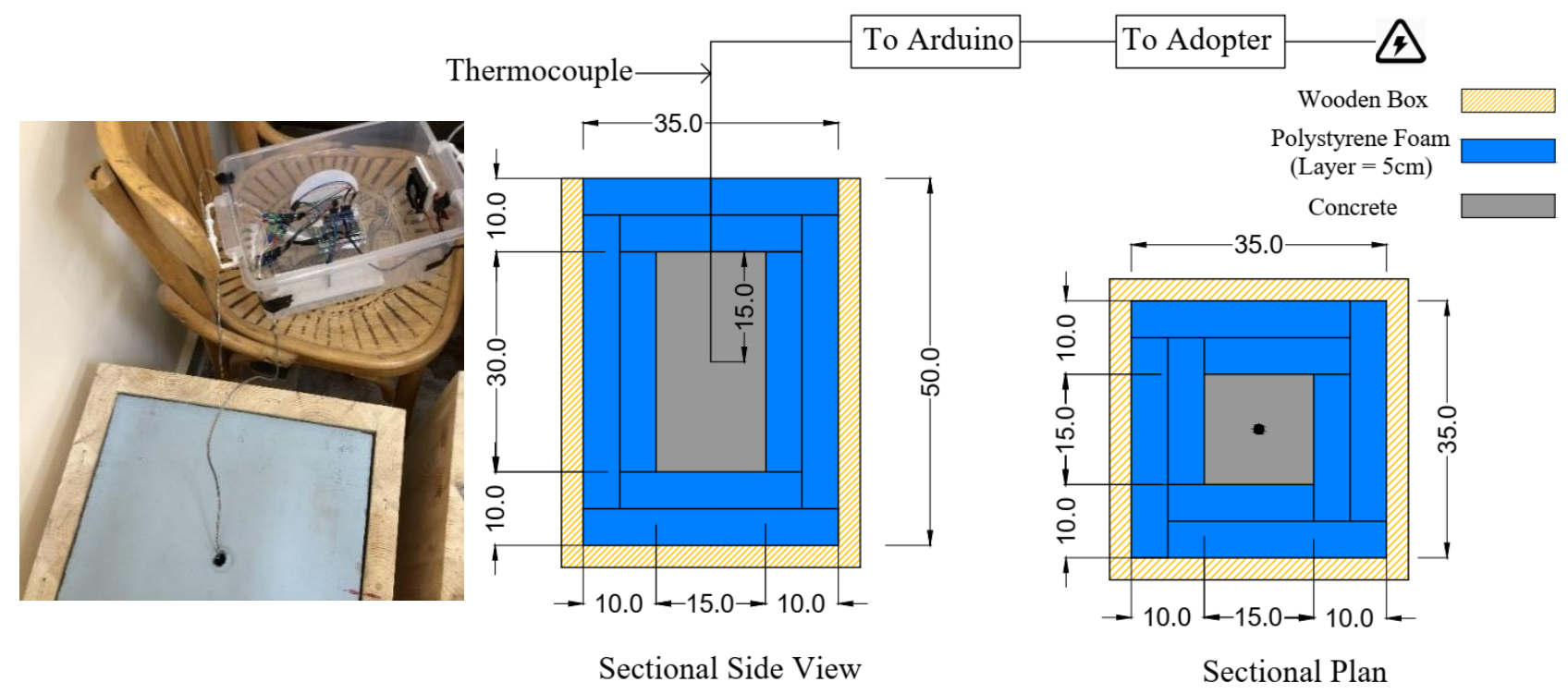

Figure 4: Schematic diagram of the semi adiabatic test (Dimensions in $\mathrm{cm}$ ) 


\subsubsection{Heat Evolution of Mass Concrete}

The development of mass concrete hardening temperature for different types of cement was estimated on a cubic specimen $(1 \mathrm{~m} \times 1 \mathrm{~m} \times 1 \mathrm{~m})$ which was thermally insulated by extruded polystyrene foam with thickness of $5 \mathrm{~cm}$ from all directions except the surface of the sample to study the effect of insulation on temperature changes [Thermal gradient and temperature difference] and the inner sides of the foam were covered with a plastic bag (Thick nylon) to prevent any water absorption and leakage of concrete. Thermocouples type $\mathrm{k}$ were used for estimating temperature in mass concrete. Set up for the heat evolution of mass concrete is shown in Figure (5). Heat evolution measurements were taken at five points $[\mathrm{C}$ : in the center of the sample, A: $5 \mathrm{~cm}$ from the middle of the side surface, $\mathrm{B}$ : in the mid distance between $A$ and $C, E: 5 \mathrm{~cm}$ from the center of the surface and D: in the mid distance between $\mathrm{C}$ and $\mathrm{E}]$ and an additional Thermocouple type $\mathrm{k}$ was used to measure the ambient temperature. The readings were recorded every five minutes and continued for seven days after casting the test sample.
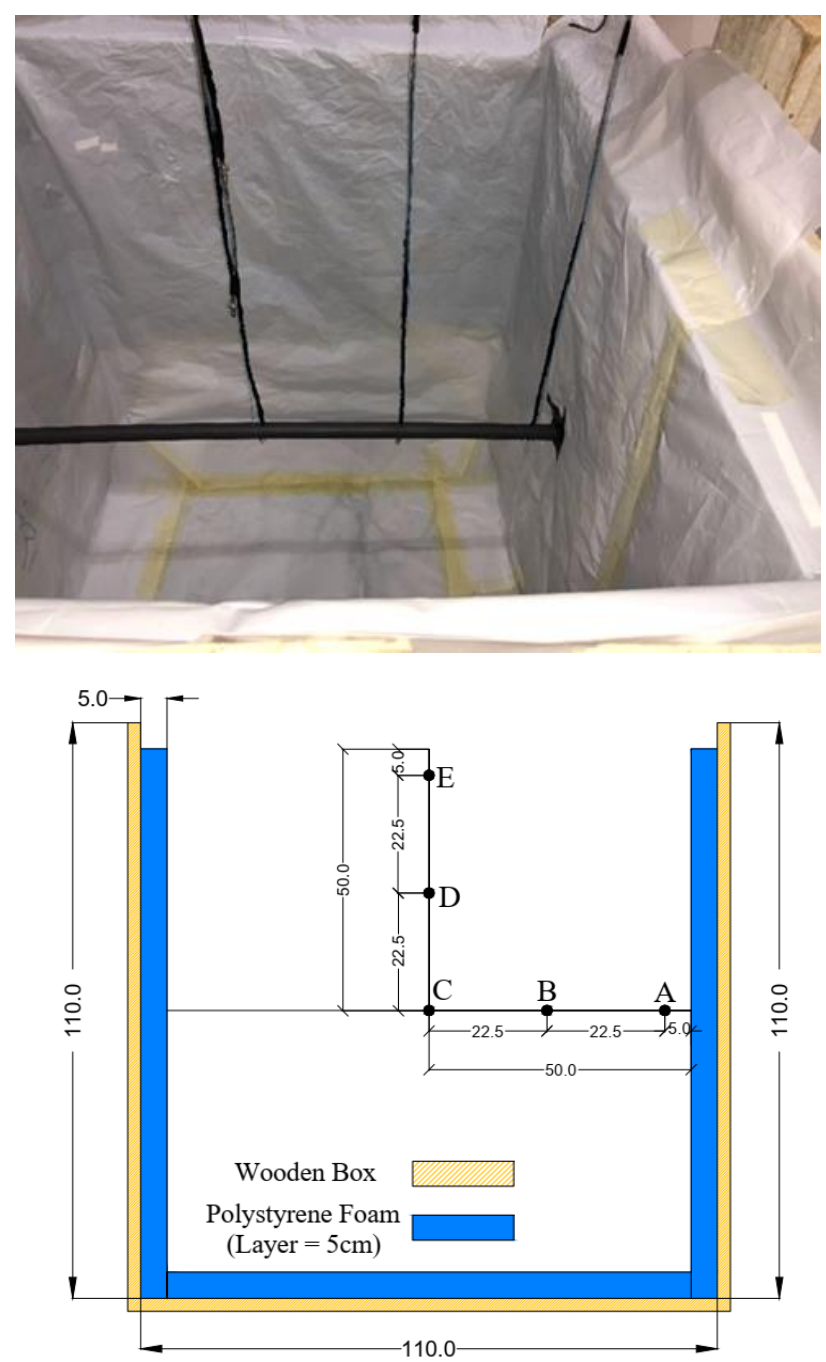

Figure 5: Set up for heat evolution test in mass concrete and fixation points (Dimensions in $\mathbf{c m}$ )

\subsubsection{Compressive Strength of Hardened Concrete}

Compressive strength of hardened concrete was done on cube specimens after 3, 7, 28 and 56 days.

\section{RESULTS AND DISCUSSION}

\subsection{Fresh Concrete Properties}

The experimental results obtained from slump test and unit weight test are presented in Table (6). According to the table, moderate heat of hydration cement [Type II $(\mathrm{MH})$ ] exhibited the highest slump for all phases in the research. whereas, blast furnace cement [CEM III / A $(42.5 \mathrm{~N})$ ] has the lowest slump in all phases except for concrete mix in phase (2). It's also clear that, replacement of cement by silica fume and metakaolin led to a decrease in slump, but when the proportion of fly ash increased, the slump increased comparing to reference mixes containing CEM I.

Table 6: Properties of fresh concrete

\begin{tabular}{|c|c|c|}
\hline \multicolumn{3}{|c|}{ Phase (1) } \\
\hline Binder & $\begin{array}{c}\text { Initial Slump } \\
\text { (cm) }\end{array}$ & Density $\left(\mathrm{kg} / \mathrm{m}^{3}\right)$ \\
\hline CEM I & 23.5 & 2450 \\
\hline CEM III / A & 22 & 2342 \\
\hline CEM I - SRC & 22.5 & 2408 \\
\hline CEM II / A-P & 22.5 & 2520 \\
\hline CEM II / B-P & 23 & 2158 \\
\hline Type II (MH) & 24.5 & 2425 \\
\hline CEM I + 30 \% FA & 24.5 & 2336 \\
\hline CEM I + 50 \% FA & 26 & 2297 \\
\hline CEM I + $10 \%$ SF & 20 & 2315 \\
\hline CEM I + $10 \%$ MK & 23 & 2353 \\
\hline CEM I + $15 \%$ MK & 21 & 2277 \\
\hline \multicolumn{3}{|c|}{ Phase (2) } \\
\hline Binder & $\begin{array}{c}\text { Initial Slump } \\
(\mathbf{c m})\end{array}$ & Density $\left(\mathrm{kg} / \mathrm{m}^{3}\right)$ \\
\hline CEM I & 21 & 2550 \\
\hline CEM II / A-P & 21 & 2415 \\
\hline CEM III / A & 23 & 2370 \\
\hline CEM I - SRC & 23 & 2412 \\
\hline CEM II / B-P & 24 & 2427 \\
\hline Type II (MH) & 26 & 2390 \\
\hline CEM I + 30 \% FA & 22 & 2361 \\
\hline CEM I + 50 \% FA & 24.5 & 2304 \\
\hline CEM I + 10 \% SF & 21 & 2393 \\
\hline CEM I + $10 \%$ MK & 20.5 & 2448 \\
\hline \multicolumn{3}{|c|}{ Phase (3) } \\
\hline Binder & $\begin{array}{l}\text { Initial Slump } \\
(\mathrm{cm})\end{array}$ & Density $\left(\mathrm{kg} / \mathrm{m}^{3}\right)$ \\
\hline CEM I & 23 & 2495 \\
\hline CEM III / A & 22 & 2410 \\
\hline CEM I - SRC & 24 & 2441 \\
\hline CEM II / A-P & 25.5 & 2443 \\
\hline Type II (MH) & 26 & 2366 \\
\hline
\end{tabular}




\subsection{Effect of Cement Type on Hydration Heat Evolution of Concrete}

The semi adiabatic test results for heat evolution for phases (1) and (3) of concrete mixes containing cement only as binder material are shown in Figures (6) and (7) respectively. The tests showed that the behavior of hydration heat rate in the two phases was similar. It is clear that for phase (1) and phase (3), the reference cement [CEM I] has the highest rate of heat evolution due to hydration process with peak temperature $59.5^{\circ} \mathrm{C}$ after 13.92 hours and $56.5^{\circ} \mathrm{C}$ after 18.1 hours respectively. whereas, [CEM III / A] cement has the lowest rate of heat evolution with peak temperature $49.5^{\circ} \mathrm{C}$ after 22.83 hours and $48.75^{\circ} \mathrm{C}$ after 23.8 hours respectively. Other types of cement used showed a lower rate of heat evolution than the reference cement in the two phases due to the low content of $\mathrm{C}_{3} \mathrm{~A}$ and $\mathrm{C}_{3} \mathrm{~S}$.

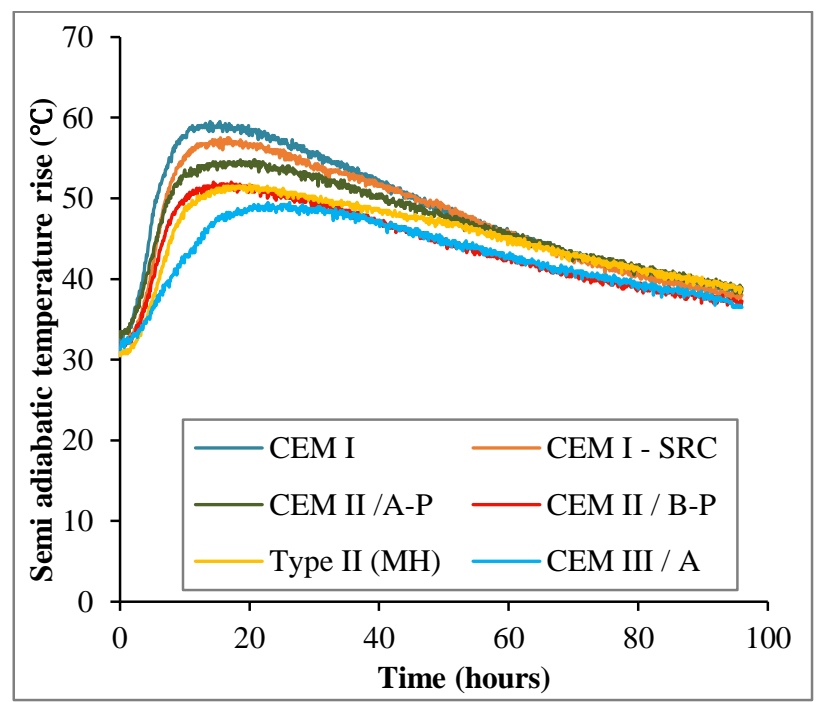

Figure 6: Effect of cement type on the hydration heat evolution for phase (1)

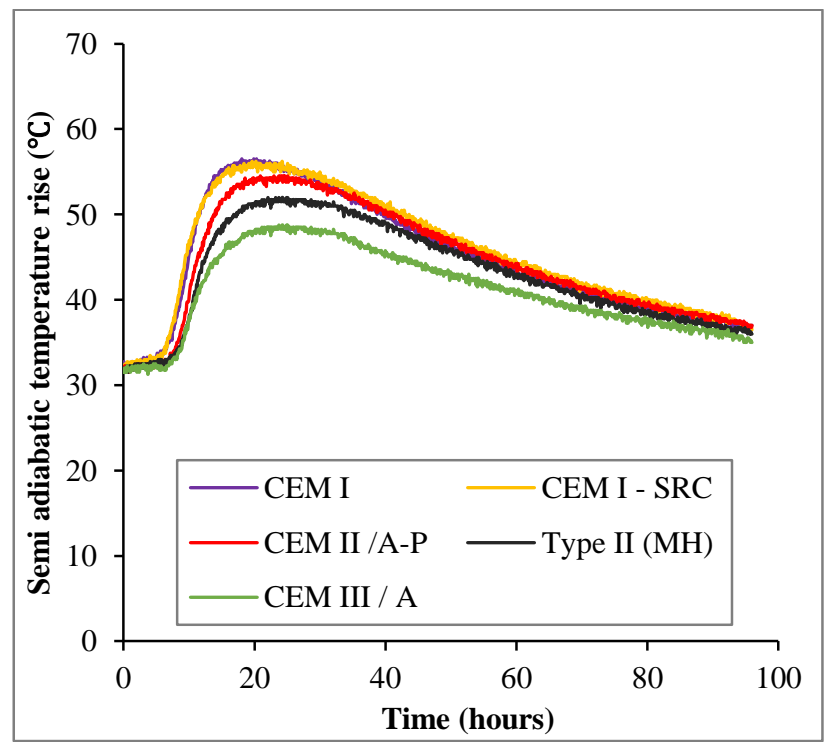

Figure 7: Effect of cement type on the hydration heat evolution for phase (3)
Table (7) summarizes the effect of cement type on peak temperature for phases (1) and (3). It is clear that [CEM II /B-P] and [Type II (MH)] cements in phase (1), [CEM I] and [CEM I - SRC] cements in phase (3) have almost the same peak, but the difference was in the time of this peak, since [CEM II /B-P] and [CEM I] led to rapid temperature growth in phase (1) and (3) respectively.

Table 7: Effect of cement type on peak temperature for phases (1) and (3)

\begin{tabular}{|c|c|c|c|c|c|c|}
\hline \multirow{2}{*}{$\begin{array}{c}\text { Cement } \\
\text { type }\end{array}$} & \multicolumn{2}{|c|}{$\begin{array}{c}\text { Peak } \\
\text { temperature } \\
\left({ }^{\circ} \mathrm{C}\right)\end{array}$} & \multicolumn{2}{|c|}{$\begin{array}{c}\text { Time of peak } \\
\text { temperature } \\
\text { (Hours) }\end{array}$} & \multicolumn{2}{|c|}{ Reduction \% } \\
\hline & $\begin{array}{c}\text { Phase } \\
1 \\
\end{array}$ & $\begin{array}{c}\text { Phase } \\
\mathbf{3} \\
\end{array}$ & $\begin{array}{c}\text { Phase } \\
1\end{array}$ & $\begin{array}{c}\text { Phase } \\
3 \\
\end{array}$ & $\begin{array}{c}\text { Phase } \\
1\end{array}$ & $\begin{array}{c}\text { Phase } \\
\mathbf{3} \\
\end{array}$ \\
\hline CEM I & 59.5 & 56.5 & 13.92 & 18.1 & - & - \\
\hline $\begin{array}{c}\text { CEM I - } \\
\text { SRC } \\
\end{array}$ & 57.5 & 56.25 & 15.5 & 19.7 & 3.36 & 0.44 \\
\hline $\begin{array}{c}\text { CEM II } \\
\text { /A-P }\end{array}$ & 54.75 & 54.5 & 18.58 & 20.9 & 7.98 & 3.54 \\
\hline $\begin{array}{c}\text { CEM II / } \\
\text { B-P }\end{array}$ & 52 & - & 14.42 & - & 12.61 & - \\
\hline $\begin{array}{c}\text { Type II } \\
\text { (MH) }\end{array}$ & 51.75 & 52 & 20 & 22.1 & 13.03 & 7.96 \\
\hline $\begin{array}{c}\text { CEM III / } \\
\text { A }\end{array}$ & 49.5 & 48.75 & 22.83 & 23.8 & 16.81 & 13.72 \\
\hline
\end{tabular}

In phase (2), the reference cement [CEM I] has the highest rate of heat evolution due to hydration process with peak temperature $60.25^{\circ} \mathrm{C}$ after 14.5 hours. whereas, [Type II (MH)] cement has the lowest rate of heat evolution with peak temperature $53{ }^{\circ} \mathrm{C}$ after 24.6 hours as shown in Figure (8). Other types of cement used in this phase showed a lower rate of heat evolution than the reference cement. [CEM II /B-P] and [CEM III / A] cements have almost the same peak, but the difference was in the time of this peak and similarly, [CEM I] and [CEM I - SRC] since [CEM II /B-P] and [CEM I] led to rapid temperature growth. Table (8) summarizes the effect of cement type on peak temperature for phase (2).

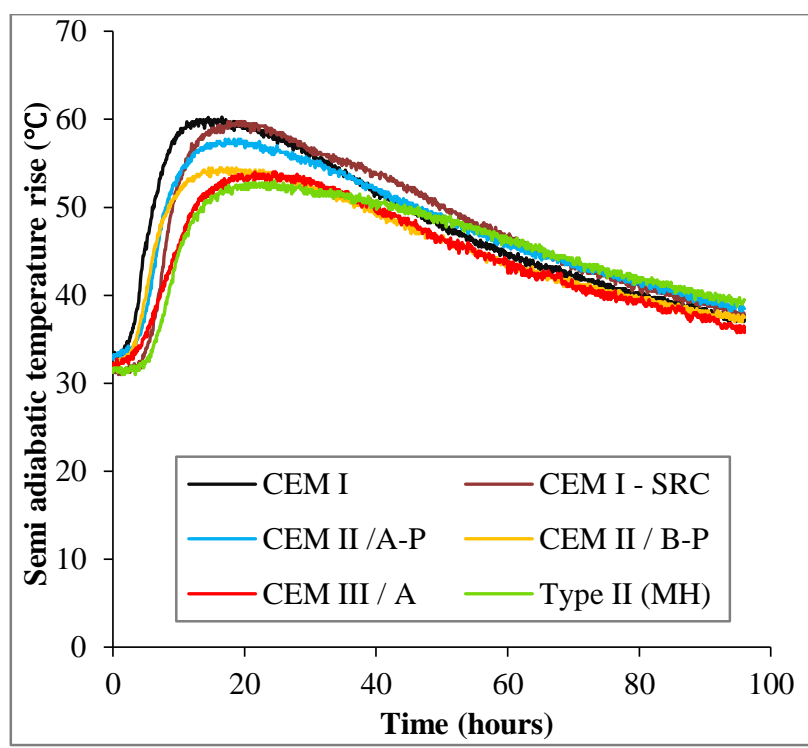

Figure 8: Effect of cement type on the hydration heat evolution for phase (2) 
Table 8: Effect of cement type on peak temperature for phase (2)

\begin{tabular}{|c|c|c|c|}
\hline Cement type & $\begin{array}{c}\text { Peak } \\
\text { temperature } \\
\left({ }^{\circ} \mathrm{C}\right)\end{array}$ & $\begin{array}{c}\text { Time of peak } \\
\text { temperature } \\
(\text { Hours })\end{array}$ & $\begin{array}{c}\text { Reduction } \\
\%\end{array}$ \\
\hline CEM I & 60.25 & 14.5 & - \\
\hline CEM I - SRC & 59.75 & 17.5 & 0.83 \\
\hline CEM II /A-P & 57.75 & 17.1 & 4.15 \\
\hline CEM II / B-P & 54.5 & 14.6 & 9.54 \\
\hline CEM III / A & 54 & 21.6 & 10.37 \\
\hline Type II (MH) & 53 & 24.6 & 12.03 \\
\hline
\end{tabular}

\subsection{Effect of Supplementary Cementitious Materials (SCMs) on Hydration}

The experimental results obtained from the semi adiabatic test to investigate the effect of (SCMs) on heat evolution of concrete mixes for phases (1) and (2) are shown in Figures (9) and (10) respectively.

The tests in phase (1) showed that the highest rate of heat evolution due to hydration process was in case of partial replacement of [CEM I] by $15 \% \mathrm{MK}$. whereas, the lowest rate was in case of partial replacement of [CEM I] by $50 \%$ FA as shown in Figure (9).

Partial replacement of [CEM I] by MK led to rapid temperature growth. In case of $15 \% \mathrm{MK}$, the maximum temperature of hydration increased to $61.25{ }^{\circ} \mathrm{C}$ which means an increase by $2.94 \%$ comparing to reference cement. whereas, it dropped to $58.5{ }^{\circ} \mathrm{C}$ in case of $10 \%$ MK which means reduction about $1.68 \%$ comparing to reference cement.

The tests showed that the addition of SF to concrete mix resulted in a slight decrease in the hydration heat and a delay in the time of peak temperature. For $10 \%$ [CEM I] replacement by $\mathrm{SF}$, the maximum temperature of hydration dropped to $58{ }^{\circ} \mathrm{C}$ which means reduction about $2.52 \%$ comparing to reference cement.

The amount of hydration heat generated was decreased with partial replacement of [CEM I] by FA. The maximum temperature of hydration recorded was $53.5^{\circ} \mathrm{C}$ and $51{ }^{\circ} \mathrm{C}$ which means reduction about $10.1 \%$ and $14.3 \%$ in case of $30 \%$ and $50 \%$ FA respectively comparing to reference cement.

The tests in phase (2) showed that the highest rate of heat evolution due to hydration process was in case of partial replacement of [CEM I] by $10 \% \mathrm{SF}$. whereas, the lowest rate was in case of partial replacement of [CEM I] by $50 \% \mathrm{FA}$ as shown in Figure (10). The maximum temperature of hydration for $10 \% \mathrm{SF}$ increased to $62.5{ }^{\circ} \mathrm{C}$ which means an increase by $3.73 \%$ comparing to reference cement.

Partial replacement of [CEM I] by $10 \% \mathrm{MK}$ had the same behavior as reference cement in this phase and there was no significant change in the maximum temperature recorded.
FA in this phase had the same behavior as phase (1). The maximum temperature of hydration recorded was 56 ${ }^{\circ} \mathrm{C}$ and $52.25{ }^{\circ} \mathrm{C}$ which means reduction about $7.1 \%$ and $13.3 \%$ in case of $30 \%$ and $50 \%$ FA respectively comparing to reference cement.

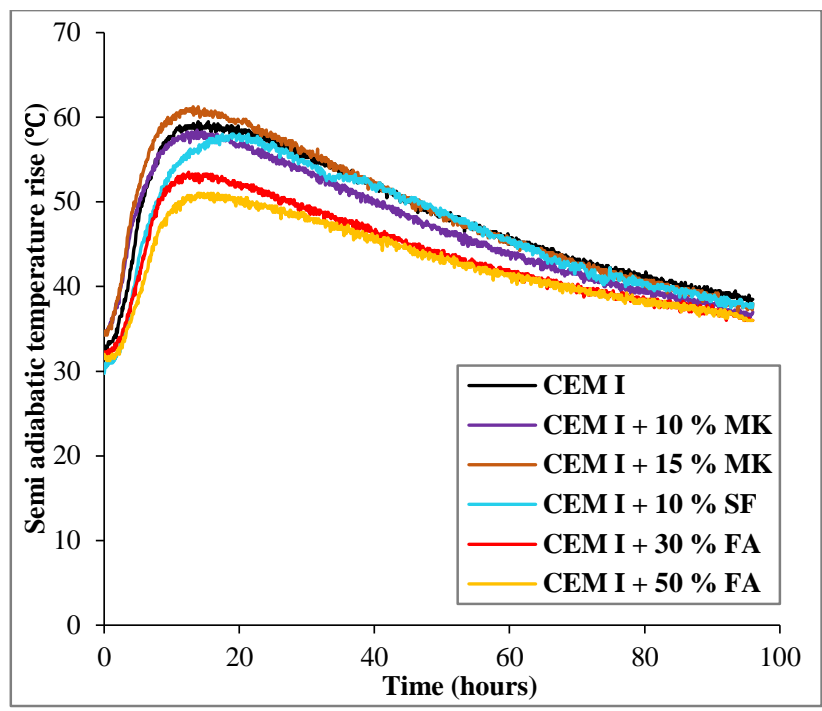

Figure 9: Effect of (SCMs) on the hydration heat evolution for phase (1)

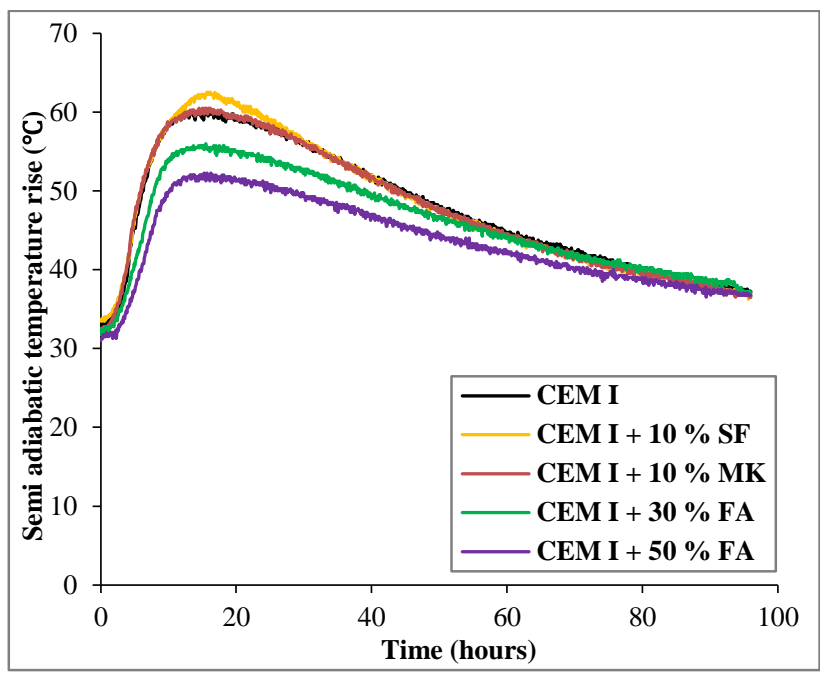

Figure 10: Effect of (SCMs) on the hydration heat evolution for phase (2)

\subsection{Effect of Water - Binder Ratio on Hydration}

\subsubsection{Concrete Mixes Incorporating Cement as Binder}

The effect of $w / b$ ratio on the hydration heat rate is evident in Figure (11) which shows that when w/b ratio increased, heat evolution due to hydration process decreased regardless the type of the used cement 
The w/b ratio had a little effect on the heat evolution of [CEM I] as shown in Figure (11-a), since the maximum temperature recorded was $60.25{ }^{\circ} \mathrm{C}$ and $59.5{ }^{\circ} \mathrm{C}$ for $\mathrm{w} / \mathrm{b}$ ratios 0.4 and 0.5 respectively. which means reduction about $1.2 \%$. The highest effect of $\mathrm{w} / \mathrm{b}$ ratio was in case of [CEM III / A] as shown in Figure (11-f), since the maximum temperature recorded was $54{ }^{\circ} \mathrm{C}$ and $49.5^{\circ} \mathrm{C}$ for
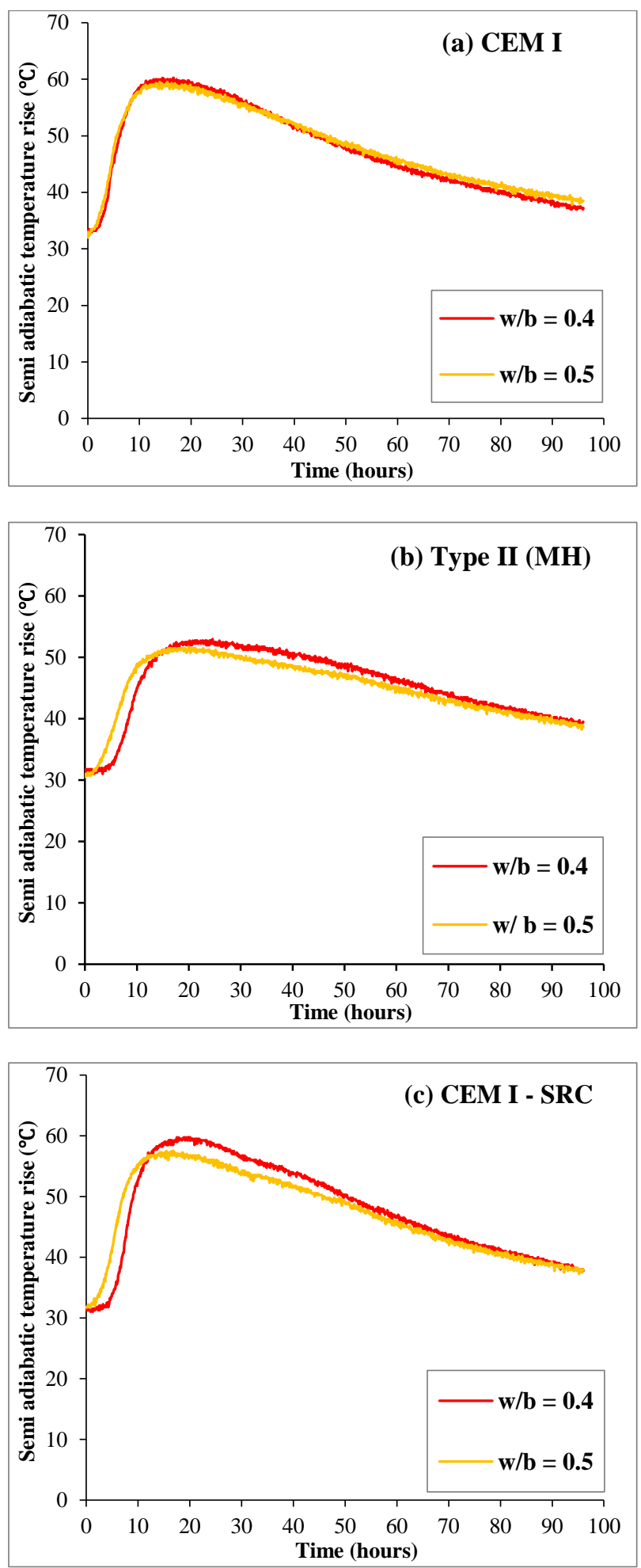

w/b ratios 0.4 and 0.5 respectively which means reduction about $8.3 \%$.

The reduction in peak temperature was $2.4 \%, 3.8 \%$, $4.6 \%$ and $5.2 \%$ for Type II (MH), CEM I - SRC, CEM II /B-P and CEM II /A-P cement respectively.

According to figure (11), heat dissipation rate with w/b 0.4 was higher than the rate with w/b 0.5 .
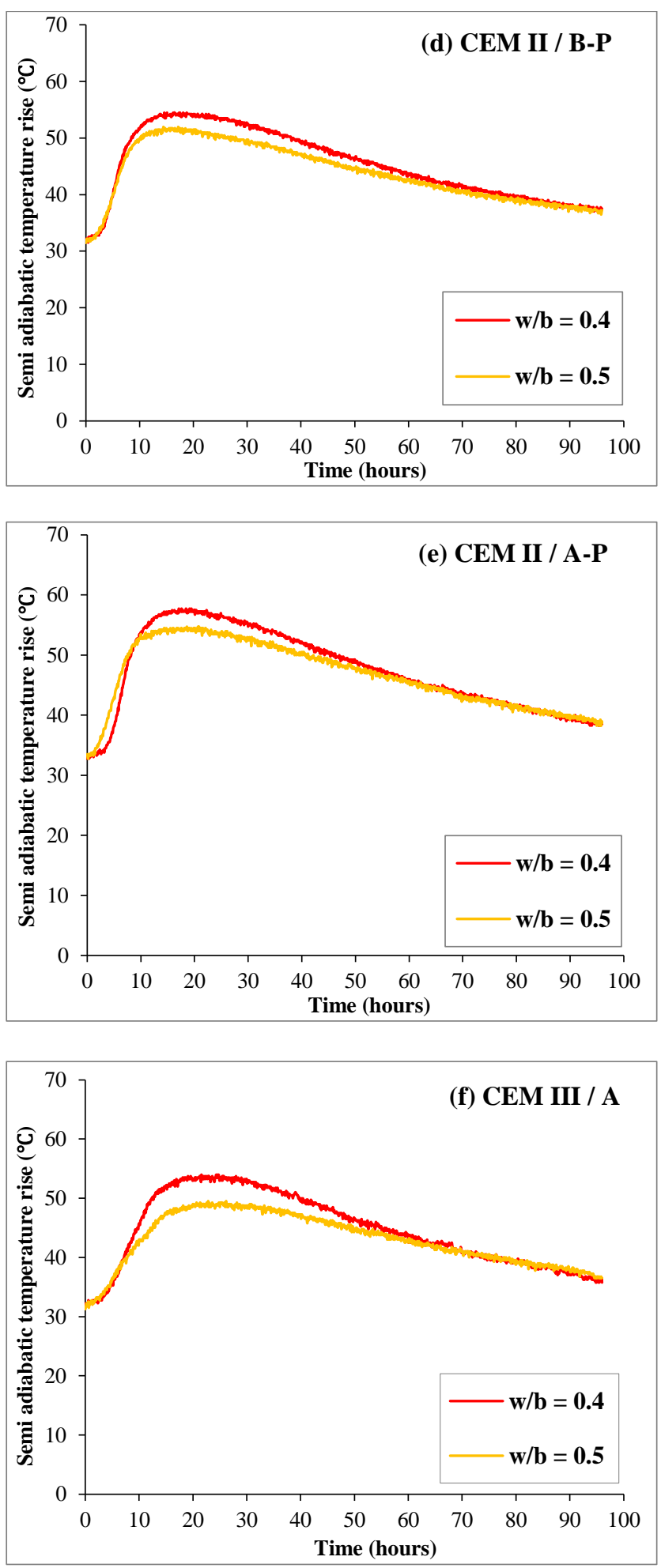

Figure 11: Effect of $w / b$ ratio on the hydration heat evolution of different types of cement 


\subsubsection{Concrete Mixes Incorporating Cement and SCMs as Binder}

According to Figure (12), the concrete with w/b ratio 0.4 showed higher hydration heat evolution rate than concrete with $\mathrm{w} / \mathrm{b}$ ratio 0.5 regardless of the type of SCMs used in concrete, and this means that when the w/b ratio increased, the heat evolution due to hydration process decreased, because water has a much larger heat capacity than anhydrous cement.

In case of partial replacement of [CEM I] by $30 \%$ FA as shown in Figure (12-a), the maximum temperature recorded was $56{ }^{\circ} \mathrm{C}$ and $53.5{ }^{\circ} \mathrm{C}$ for $\mathrm{w} / \mathrm{b}$ ratios 0.4 and 0.5 respectively, which means reduction about $4.5 \%$.
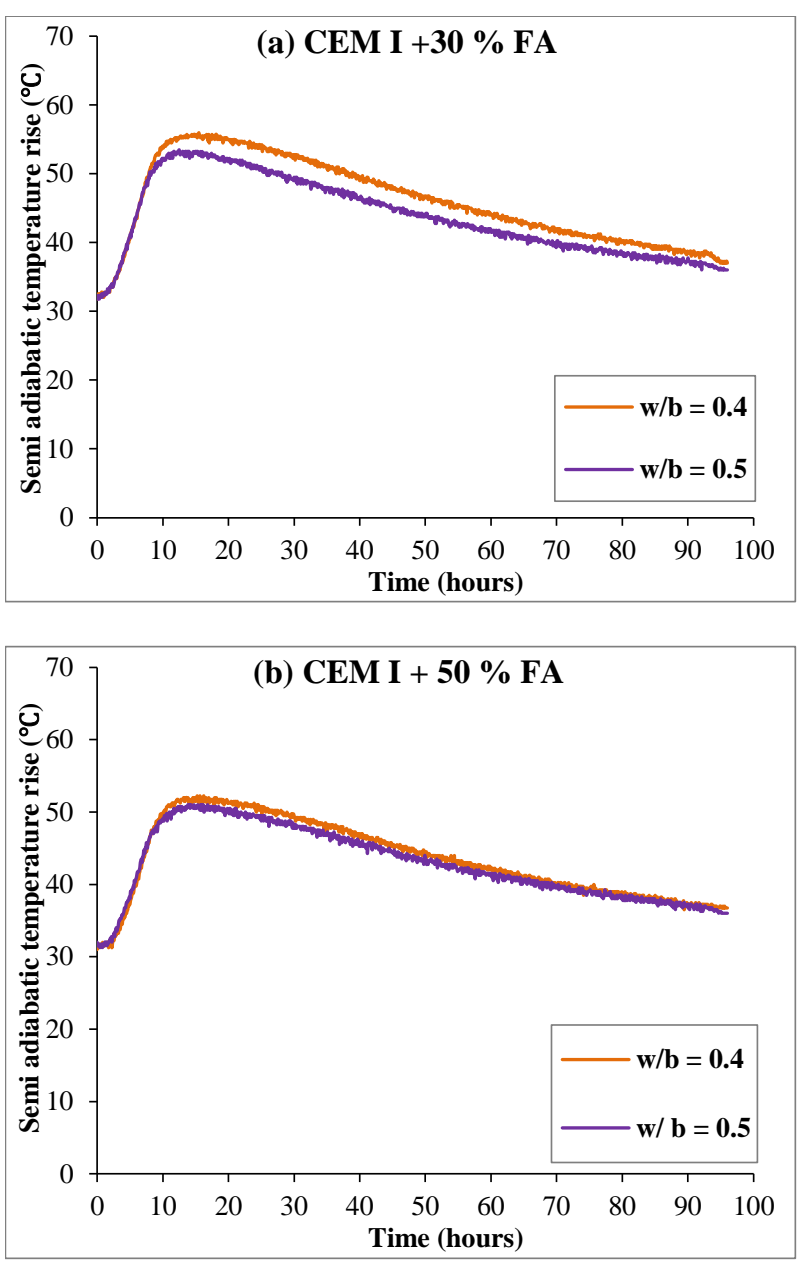

Whereas, for $50 \% \mathrm{FA}$ the maximum temperature decreased from $52.25{ }^{\circ} \mathrm{C}$ to $51{ }^{\circ} \mathrm{C}$ which means reduction about $2.4 \%$ as shown in Figure (12-b).

In case of partial replacement of [CEM I] by $10 \% \mathrm{SF}$, the effect of the w/b ratio was evident as shown in Figure (12-c). The maximum temperature decreased from $62.5^{\circ} \mathrm{C}$ to $58{ }^{\circ} \mathrm{C}$ which means reduction about $7.2 \%$.

The effect of the $w / b$ ratio was slightly evident in case of $10 \% \mathrm{MK}$ as shown in Figure (12-d) because of the high pozzolanic action of MK. The maximum temperature decreased from $60.5^{\circ} \mathrm{C}$ to $58.5^{\circ} \mathrm{C}$ which means reduction about $3.3 \%$. So, when the $w / b$ ratio increased, this resulted in a decrease in the heat generated because of the high heat capacity of water compared to cement.
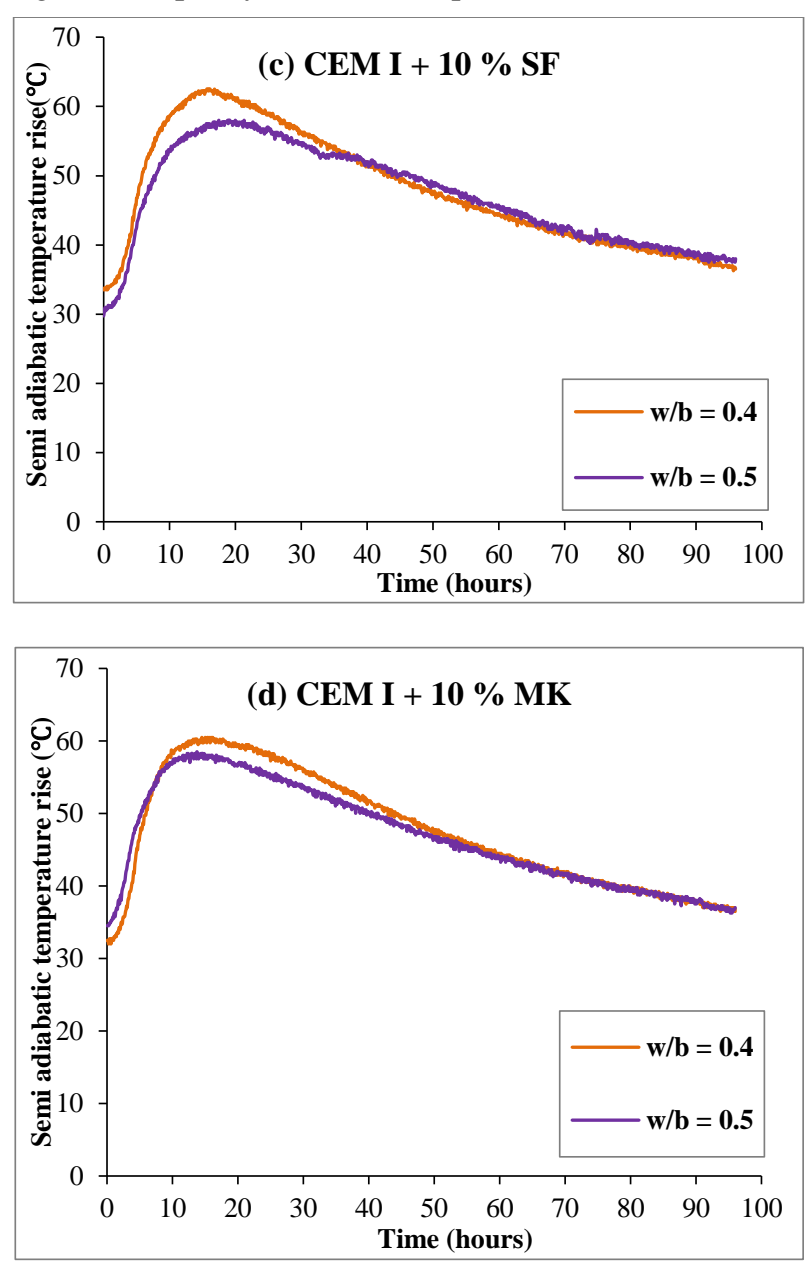

Figure 12: Effect of w/ b ratio on the hydration heat evolution of concrete containing SCMs

\subsection{Effect of Cement Content on Hydration}

The effect of cement content is evident from Figure (13), which shows that when the cement content decreased from 450 to $350 \mathrm{~kg} / \mathrm{m}^{3}$ the hydration heat evolution rate decreased regardless the type of cement used.

In case of [CEM I] as shown in Figure (13-a), the maximum temperature recorded due to hydration process was $60.25{ }^{\circ} \mathrm{C}$ and $56.5^{\circ} \mathrm{C}$ after 14.5 and 18.1 hours for cement content 450 and $350 \mathrm{~kg} / \mathrm{m}^{3}$ respectively.
Therefore, decreasing the cement content resulted in a reduction about $6.2 \%$.

The maximum effect appeared when using [CEM III / A] cement as the maximum temperature recorded due to hydration process was $54{ }^{\circ} \mathrm{C}$ and $48.75{ }^{\circ} \mathrm{C}$ after 21.6 and 23.8 hours for cement content 450 and $350 \mathrm{~kg} / \mathrm{m}^{3}$ respectively as shown in Figure (13-b). Therefore, decreasing the cement content resulted in a reduction about $9.72 \%$.

For [CEM I - SRC] the maximum temperature of hydration decreased from $59.75^{\circ} \mathrm{C}$ to $56.25^{\circ} \mathrm{C}$ which 
means reduction about $5.9 \%$ and it was recorded after 17.5 and 19.7 hours for cement content 450 and 350 $\mathrm{kg} / \mathrm{m}^{3}$ respectively as shown in Figure (13-c).

In case of [CEM II / A-P] cement the maximum temperature of hydration dropped from $57.75^{\circ} \mathrm{C}$ to $54.5^{\circ} \mathrm{C}$ which means reduction about $5.6 \%$, and it was recorded after 17.1 and 20.9 hours for cement content 450 and 350 $\mathrm{kg} / \mathrm{m}^{3}$ respectively as shown in Figure (13-d).

In case of [Type II (MH)] cement the cement content had little effect on the hydration heat evolution of concrete as the maximum temperature recorded was $53{ }^{\circ} \mathrm{C}$ and $52^{\circ} \mathrm{C}$ after 24.6 and 22.1 hours for cement content 450 and $350 \mathrm{~kg} / \mathrm{m}^{3}$ respectively which means reduction about $1.9 \%$ as shown in Figure (13-e).
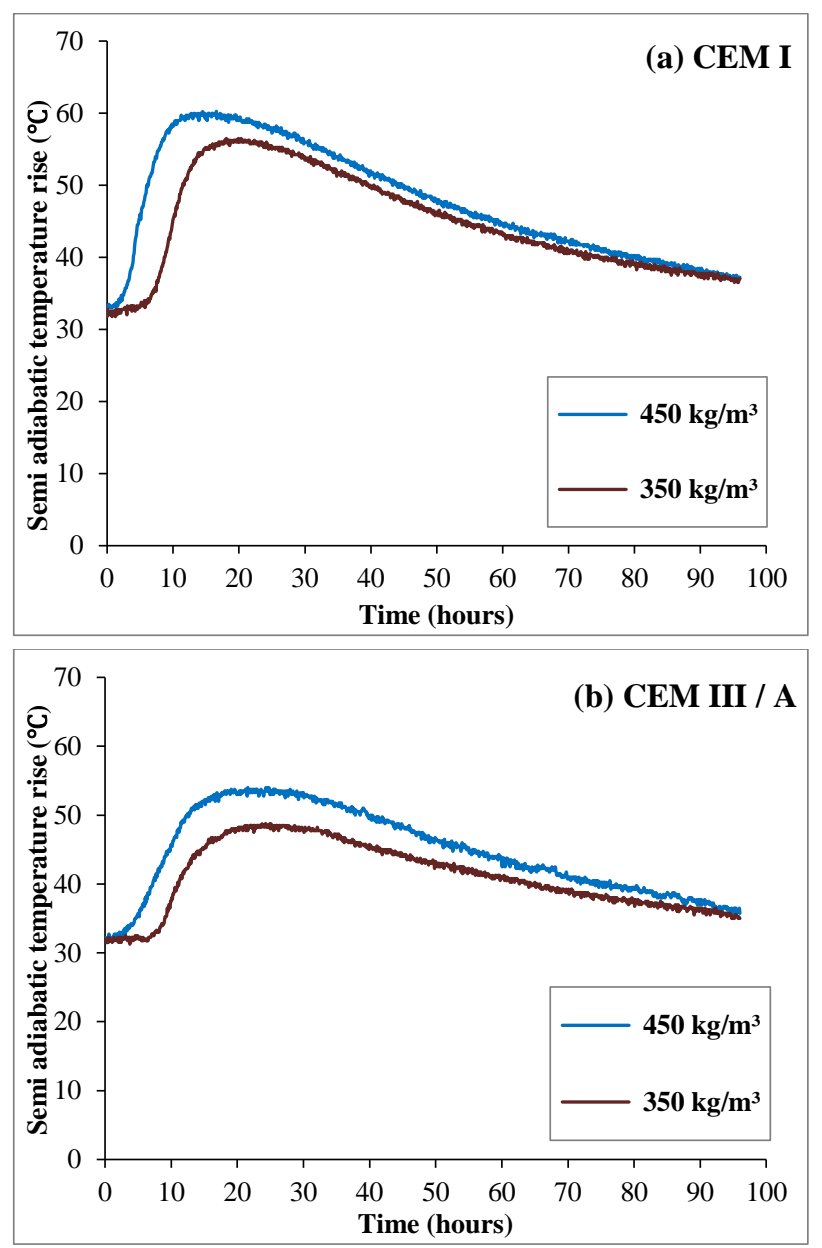
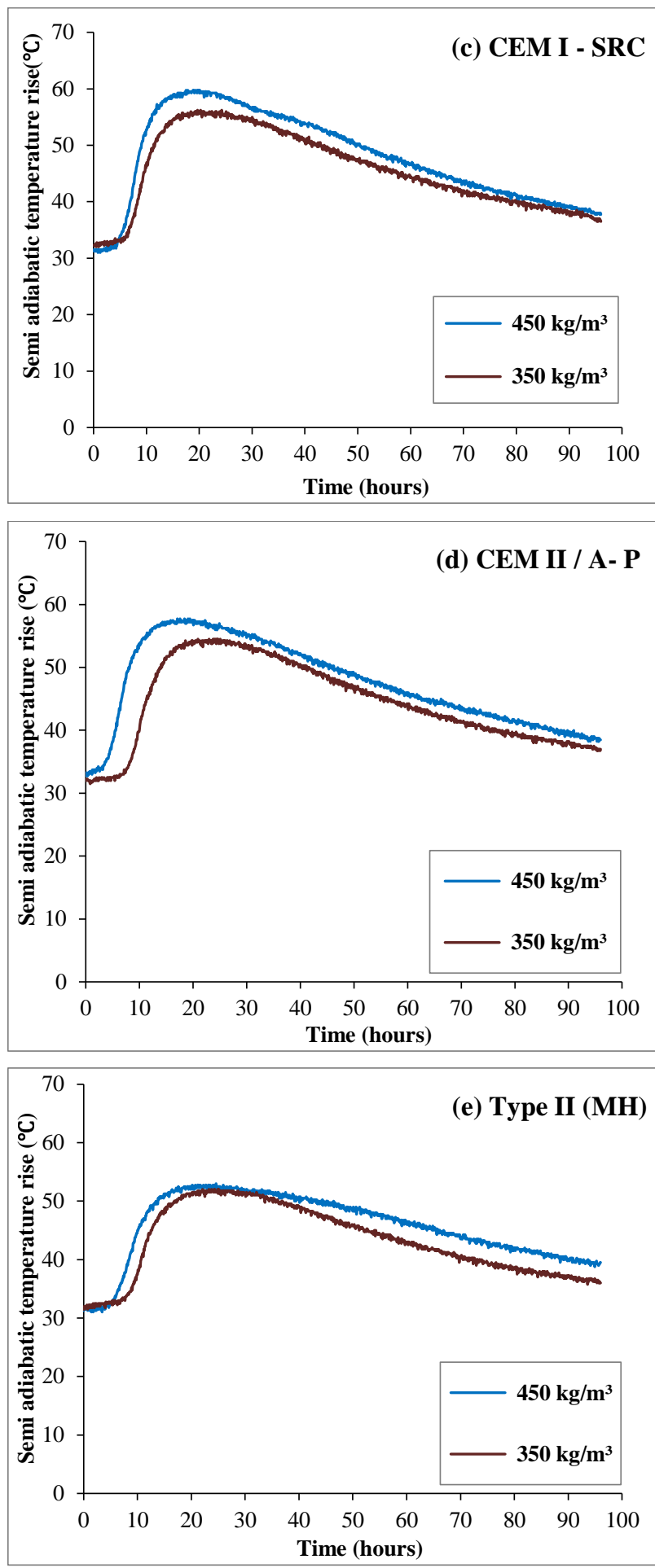

Figure 13: Effect of cement content on the hydration heat evolution rate of concrete

\subsection{Effect of Cement Type on Mass Concrete} Hardening Temperature

The development of mass concrete hardening temperature for various types of cement, with respect to time and at all locations of thermocouples are shown in Figures (14 to 17 ).

The figures show that the temperature increased at a higher rate until reaching their peak hardening temperatures then they diminished at a slower rate until arriving at thermal equilibrium The maximum hardening temperature was lower than its limit for all types of cement used.

In case of [CEM I] cement (reference cement) as shown in Figure (14), the peak hardening temperature of hydration was $66.25^{\circ} \mathrm{C}$ and it was recorded after 39 hours from casting. The maximum temperature difference between fixation points $\mathrm{C}$ and $\mathrm{E}$ (TC-TE) was $21.5^{\circ} \mathrm{C}$. Whereas, it was $13{ }^{\circ} \mathrm{C}$ between points $\mathrm{C}$ and A (TC-TA) and this explains the importance of insulation and how it affects the thermal gradient. The presence of thermal 
insulation at point $\mathrm{A}$ made a reduction in the temperature difference by $39.5 \%$ comparing with (TC-TE).

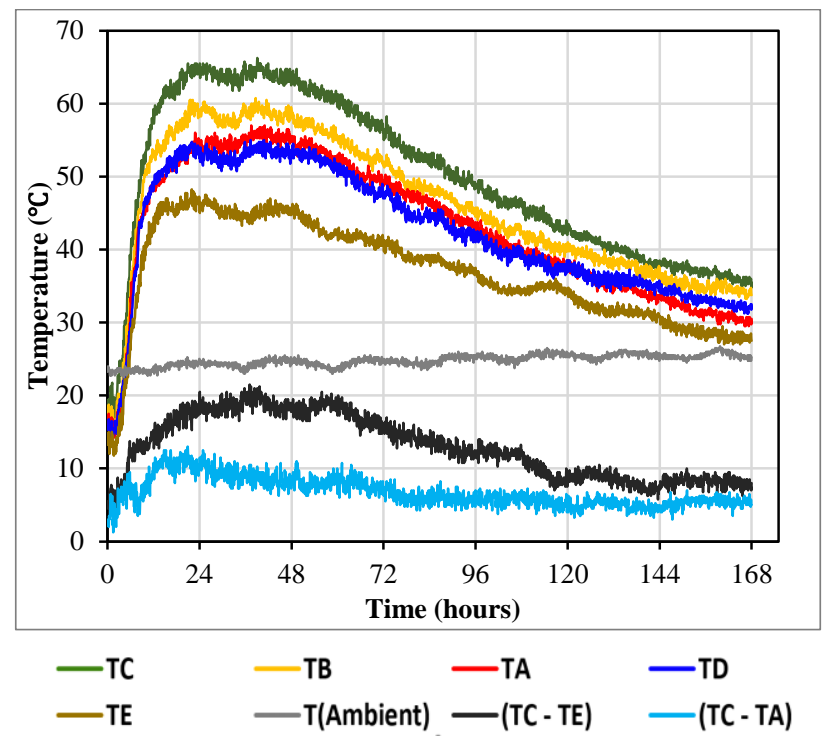

Figure 14: [CEM I] Mass concrete hardening temperature rise (Thermal gradient)

Use of [CEM I - SRC] in mass concrete resulted in a decrease of the peak temperature from $66.25^{\circ} \mathrm{C}$ to $60^{\circ} \mathrm{C}$, which means reduction about $9.4 \%$ comparing with reference cement as shown in Figure (15). The maximum temperature difference between fixation points $\mathrm{C}$ and $\mathrm{E}$ (TC-TE) was $21.25^{\circ} \mathrm{C}$. Whereas, it was $15.5^{\circ} \mathrm{C}$ between points $\mathrm{C}$ and $\mathrm{A}$ (TC-TA) which means that thermal insulation at point $\mathrm{A}$ made a reduction in the temperature difference by $27.1 \%$ comparing with (TC-TE).

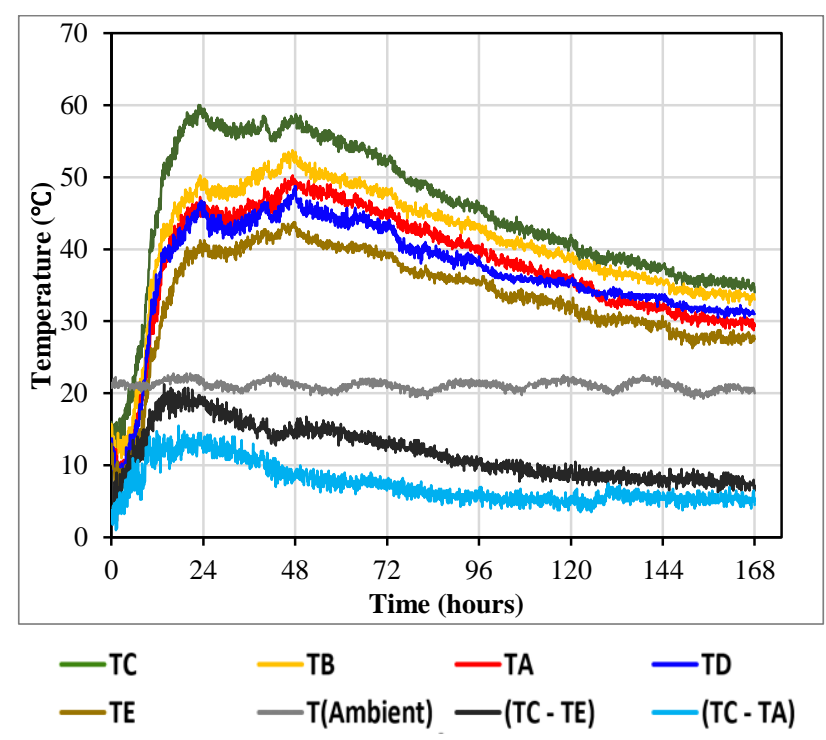

Figure 15: [CEM I - SRC] Mass concrete hardening temperature rise (Thermal gradient)

In case of [CEM II /A-P] the peak hardening temperature recorded was $56.5{ }^{\circ} \mathrm{C}$ after 38 hours which means reduction about $14.7 \%$ comparing with reference cement as shown in Figure (16). The maximum temperature difference between fixation points $\mathrm{C}$ and $\mathrm{E}$ (TC-TE) was $20.75^{\circ} \mathrm{C}$. Whereas, it was $13.25^{\circ} \mathrm{C}$ between points $\mathrm{C}$ and A (TC-TA) which means that insulation at point A made a reduction in the temperature difference by $36.1 \%$ comparing with (TC-TE).

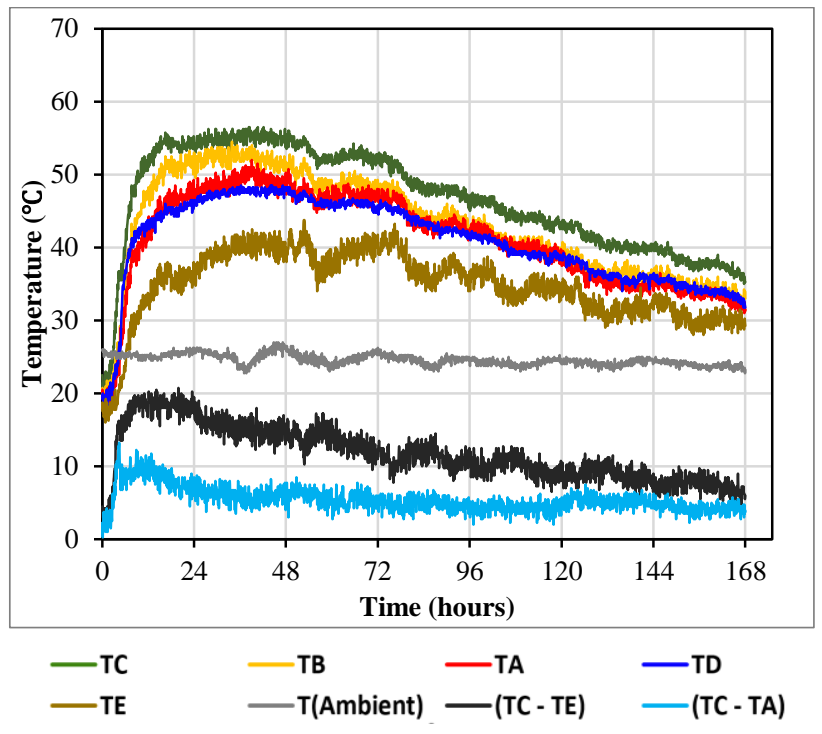

Figure 16: [CEM II /A-P] Mass concrete hardening temperature rise (Thermal gradient)

According to Figure (17), the peak temperature recoded in case of using [Type II (MH)] cement was $53.5^{\circ} \mathrm{C}$ after 26 hours which means reduction about $19.2 \%$ comparing with reference cement. The maximum temperature difference between fixation points $\mathrm{C}$ and $\mathrm{E}$ (TC-TE) was $17.5^{\circ} \mathrm{C}$. Whereas, it was $8.75^{\circ} \mathrm{C}$ between points $\mathrm{C}$ and $\mathrm{A}$ (TC-TA) which means that thermal insulation at point $\mathrm{A}$ made a reduction in the temperature difference by $50 \%$ comparing with (TC-TE).

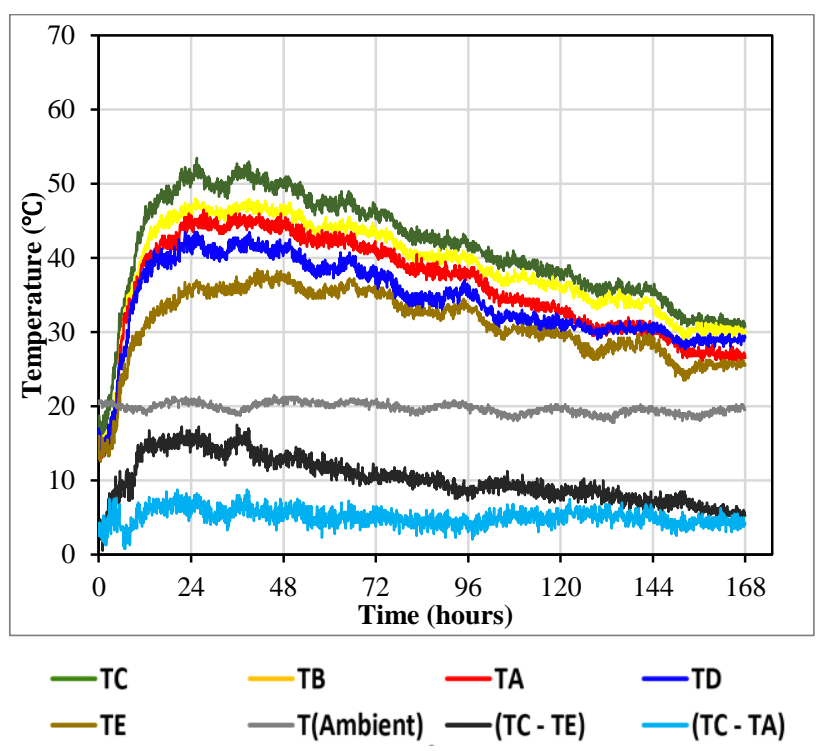

Figure 17: [Type II (MH)] Mass concrete hardening temperature rise (Thermal gradient)

\subsection{Compressive Strength of Hardened Concrete}

\subsubsection{Effect of Cement Type}

The effect of cement types on compressive strength of concrete for the three phases of concrete mixes is evident from Figures (18 to 20). The reference compressive 
strength with [CEM I] cement at 28 days was $31.6 \mathrm{MPa}$, $45 \mathrm{MPa}$ and $36.6 \mathrm{MPa}$ for phases (1), (2) and (3) respectively.

The effect of cement type on compressive strength of concrete for phase (1) is apparent from Figure (18) which shows that compressive strength with [Type II (MH)] cement was lower than reference compressive strength until 28 days, then it became slightly higher. At 28 days, its compressive strength was about $90.8 \%$ of reference compressive strength. Compressive strength of concrete with [CEM II / B-P] cement was lower than reference compressive strength at all ages of testing, as it was about $94.9 \%$ of reference compressive strength at 28 days. In concrete containing [CEM III / A] cement, its compressive strength was lower than reference compressive strength at early ages, then it became higher, as it was about $101.6 \%$ of reference compressive strength at 28 days and it had the highest compressive strength at 56 days. For concrete with [CEM I- SRC] cement, its compressive strength was higher than reference compressive strength at all ages of testing and it was about $104.4 \%$ of reference compressive strength at 28 days. In case of [CEM II/A-P] cement, its compressive strength was lower than reference compressive strength at 3 days, then it became higher for all ages. This cement led to an increase in compressive strength by $7.6 \%$ comparing to reference compressive strength at the age of 28 days.

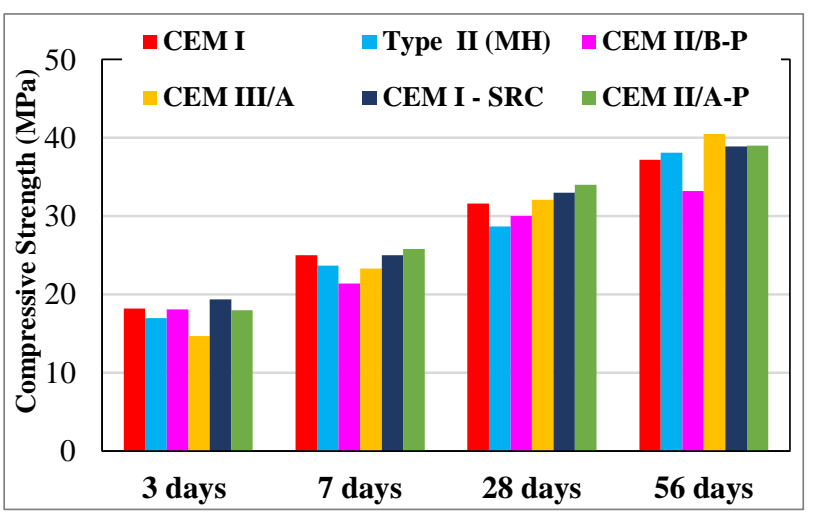

Figure 18: Concrete compressive strength for phase

(1)

The effect of cement type on compressive strength of concrete for phase (2) is evident from Figure (19) which shows that compressive strengths with [Type II (MH)], [CEM I - SRC] and [CEM II / B-P] cements were lower than reference compressive strength at all ages of testing. At 28 days, their compressive strengths were about $89.1 \%, 84.9 \%$ and $75.6 \%$ of reference compressive strength for [CEM II / B-P], [CEM I- SRC] and [Type II $(\mathrm{MH})$ ] cements respectively. Compressive strength with [CEM III/A] cement was lower than reference compressive strength until 28 days, as it was about $96.9 \%$ of reference compressive strength at 28 days and it was the highest compressive strength at 56 days.

For [CEM II /A-P] cement, its compressive strength was lower than reference compressive strength at early ages, then it became higher, as it was about $104.4 \%$ of reference compressive strength at 28 days.

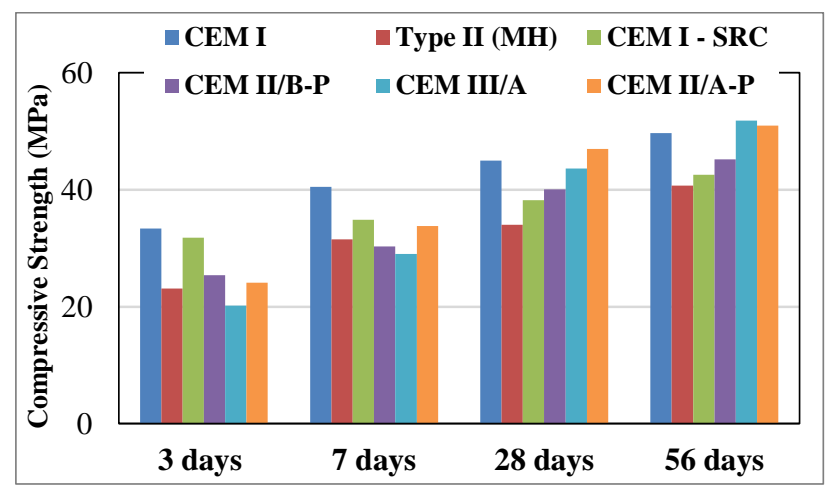

Figure 19: Concrete compressive strength for phase

(2)

The effect of cement type on compressive strength of concrete for phase (3) is evident from Figure (20) which shows that compressive strengths with [Type II (MH)] and [CEM I - SRC] cements were lower than reference compressive strength at all ages of testing. At 28 days, their compressive strengths were about $97.5 \%$ and $88.8 \%$ of reference compressive strength for [CEM I- SRC] and [Type II (MH)] cements respectively. Compressive strength of concrete with [CEM II /A-P] cement was lower than reference compressive strength until 28 days, then it became higher. At 28 days, its compressive strength was about $96.2 \%$ of reference compressive strength. In case of [CEM III / A] cement, its compressive strength was lower than reference compressive strength at early ages, then it became higher, as it was about $103.8 \%$ of reference compressive strength at 28 days and it had the highest compressive strength at 56 days.

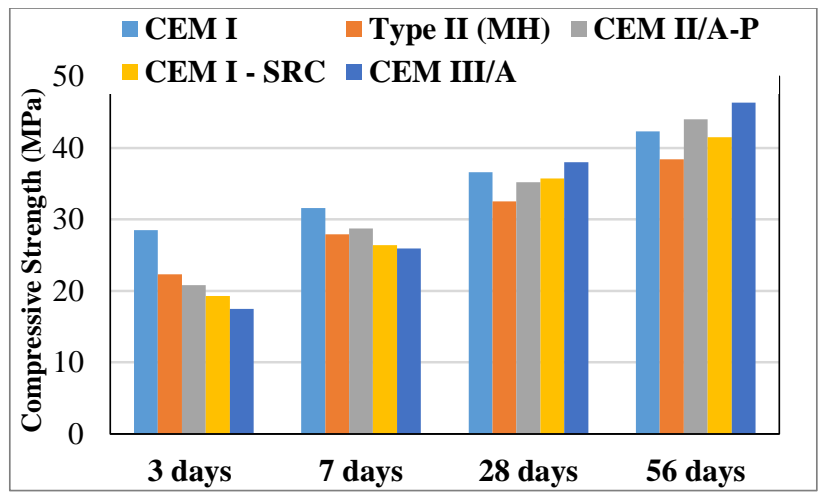

Figure 20: Concrete compressive strength for phase

(3)

\subsubsection{Effect of SCM Type}

The effect of SCMs on compressive strength of concrete for phases (1) and (2) is shown in Figures (21) and (22) respectively.

According to Figure (21), partial replacement of [CEM I] by $30 \%$ and $50 \% \mathrm{FA}$ led to a decrease in compressive strength at all ages of testing comparing with the reference concrete compressive strength. At 28 days, compressive strength was about $95.9 \%$ and $88.3 \%$ of reference compressive strength for $30 \%$ and $50 \%$ FA respectively. Compressive strength of concrete with $10 \%$ $\mathrm{SF}$ was higher than reference compressive strength at all ages of testing, and it was about $118.7 \%$ of reference 
compressive strength at 28 days. Use of metakaolin led to an increase in the early age strength comparing with other SCMs used and its compressive strength was higher than reference compressive strength at all ages of testing for the two levels of replacement. At 28 days, compressive strength was about $105.1 \%$ and $114.9 \%$ of reference compressive strength for $10 \%$ and $15 \%$ MK respectively.

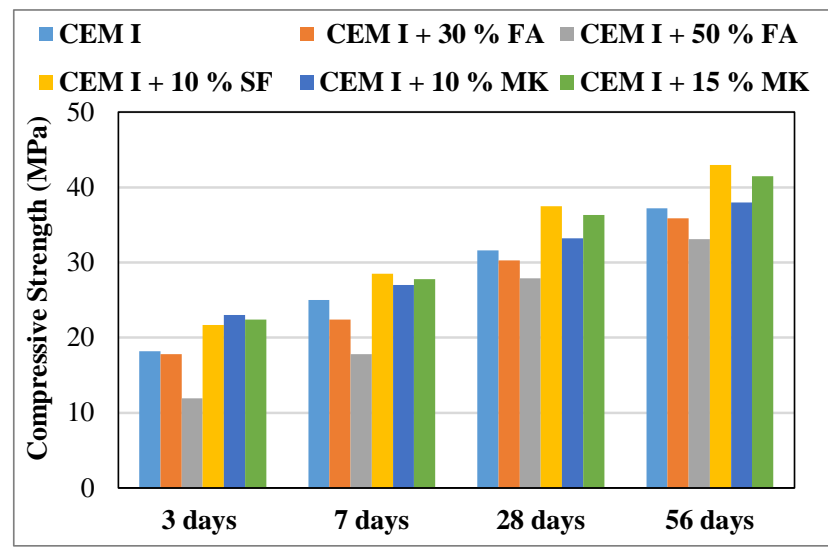

Figure 21: Compressive strength of concrete containing SCMs at phase (1)

Figure (22) shows that partial replacement of [CEM I] by $30 \%$ and $50 \%$ FA led to a decrease in compressive strength at all ages of testing comparing with reference compressive strength as phase (1). At 28 days, compressive strength was about $93.1 \%$ and $80.9 \%$ of reference compressive strength for $30 \%$ and $50 \% \mathrm{FA}$ respectively. Compressive strengths of concrete with $10 \%$ $\mathrm{SF}$ and $10 \% \mathrm{MK}$ were lower than reference compressive strength at 3 days, then they became slightly higher as they were about $102.2 \%$ and $101.1 \%$ of reference compressive strength at 28 days for $10 \% \mathrm{SF}$ and $10 \%$ MK respectively.

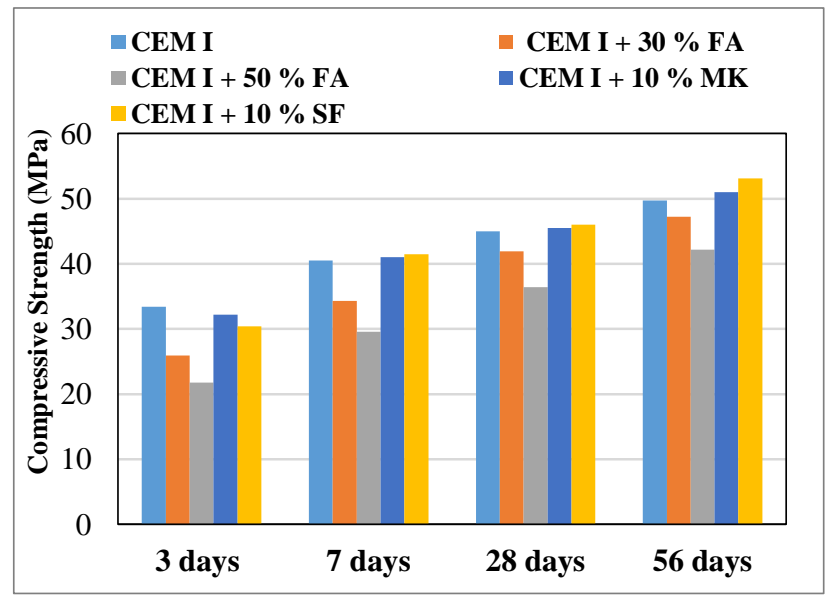

Figure 22: Compressive strength of concrete containing SCMs at phase (2)

\section{CONCLUSIONS}

The main findings of the present study are summarized as follows:
[CEM I] showed the highest heat evolution rate in all phases of testing due to the high content of $\mathrm{C}_{3} \mathrm{~A}$ and $\mathrm{C}_{3} \mathrm{~S}$. It turned out that [CEM III / A] cement was more influencing the hydration heat rate comparing to other types of cement and at the same time improved the compressive strength over a long period of time, as it had the highest compressive strength at 56 days in all phases. It reduced the maximum temperature of hydration by $16.81 \%, 13.72 \%$ and $10.37 \%$ for phases (1), (3) and (2) respectively and delayed its time of occurrence because of the high content of granulated blast furnace slag. Also, the effect of [Type II (MH)] cement on the hydration heat was evident in all phases but its compressive strength was lower than reference strength in all phases. It reduced the maximum temperature of hydration by $13.03 \%, 12.03 \%$ and $7.96 \%$ for phases (1), (2) and (3) respectively and delayed its time of occurrence due to the low content of $\mathrm{C}_{3} \mathrm{~A}$ and $\mathrm{C}_{3} \mathrm{~S}$. The effect of [CEM II / B-P] cement on the hydration heat was better than [CEM II / A-P] cement, but its compressive strength was the lowest in all phases. The significant effect of [CEM II / A-P] on the hydration heat appeared in phase (1) as the maximum temperature decreased by $7.98 \%$.

Substituting [CEM I] with MK has no significant effect on hydration heat, but when the replacement of cement with MK exceeded $10 \%$, this led to an increase in the heat generated by the hydration process. In phase (1) the use of $10 \% \mathrm{SF}$ led to a decrease in the hydration temperature by $2.52 \%$. Whereas. It led to an increase by $3.73 \%$ in phase (2). The effect of FA on the hydration heat was evident, as the higher the percentage of replacement of cement with $\mathrm{FA}$, the less the maximum temperature of hydration and compressive strength as in phases (1) and (2).

The higher the water to binder ratio, the less the maximum temperature of hydration regardless of the type of cement used. The highest effect of $\mathrm{w} / \mathrm{b}$ ratio appeared in the case of [CEM III / A] as the maximum temperature reduced by $8.3 \%$, followed by [CEM II / A-P] with reduction about $5.2 \%$.

Decreasing the cement content led to a decrease in the maximum temperature recorded. The highest effect appeared in the case of [CEM III / A] as the maximum temperature reduced by $9.72 \%$.

The lowest hardening temperature of mass concrete and best thermal gradient were registered in the case of [Type II (MH)] cement, since the maximum hardening temperature was decreased by $12.75^{\circ} \mathrm{C}$ comparing with [CEM I] and the maximum temperature difference was lower than $19^{\circ} \mathrm{C}$. Whereas, it was higher for other types of cement and this lead to thermal cracking. The thermal insulation made the maximum temperature difference less than $19{ }^{\circ} \mathrm{C}$ and this lead to limit the early age cracking.

\section{Authorship Contribution Statement}

Mohammed H.Belal: Conceptualization, Writing original draft, Formal analysis, Software, Investigation, Visualization. Shady R.Ragheb: Conceptualization (supporting), Resources, Writing - original draft (supporting), Writing - review and editing, Supervision, Project administration. Hassan M.Hassan: Supervision, Writing - Review \& Editing. 


\section{Declaration of Competing Interest}

There have been no involvements that might raise the question of bias in the work reported or in the conclusions, implications, or opinions stated.

\section{REFERENCES}

[1] H. Abeka, M. Adom-Asamoah, J. Osei Banahene, and K. Adinkrah-Appiah, "Temperature prediction models in mass concrete state of the art literature review," 2018, pp. 692-700 [Proceedings of ESTE 2015 conference].

[2] D. Zhang, X. Cai, and L. Hu, "Effect of curing temperature on hydration of calcium aluminate cement-calcium sulfate-limestone system," Journal of Materials in Civil Engineering, vol. 30, No. 9, 2018, pp. 06018011.

[3] M. Tahersima, and P. Tikalsky, "Finite element modeling of hydration heat in a concrete slab-ongrade floor with limestone blended cement," Construction and Building Materials, vol. 154, 2017, pp. 44-50.

[4] ASTM C150 / C150M - 16, "Standard specifications for portland cement," ASTM International, West Conshohocken, PA. 2016.

[5] ASTM C186 - 15a, "Standard test method for heat of hydration of hydraulic cement," ASTM International, West Conshohocken, PA. 2015.

[6] ACI Committee E-701, "Cementitious materials for concrete (Education Bulletin E3-013)," American Concrete Institute, Farmington Hills, MI, USA. 2013.

[7] Egyptian Standards-Building Materials Committee "Cement part1: composition, specifications and conformity criteria for common cements (ES 47561)," Cairo (Egypt), Egyptian Organization for Standards and Quality, EOS. 2013.

[8] B. Godart, and L. Divet, "Lessons learned from structures damaged by delayed ettringite formation and the French prevention strategy," Fifth international conference on Forensic Engineering, Institution of Civil Engineers, 12p, France. 2013, April.

[9] ASTM C150 / C150M - 12, "Standard specification for portland cement," ASTM International, West Conshohocken, PA. 2012.
[10] A. M. Neville, "Properties of concrete," 5th ed, London: Longman. 2011.

[11]British Standards Institution, "BS EN 197-1: 2011, Cement, part 1: composition, specifications and conformity criteria for common cements," BSI Standards Limited, London. 2011.

[12] S. G. Kim, "Effect of heat generation from cement hydration on mass concrete placement," Master thesis, Iowa state university. 2010.

[13]D. P. Bentz, M. A. Peltz, and J. Winpigler, "Earlyage properties of cement-based materials. II: Influence of water-to-cement ratio," Journal of materials in civil engineering, vol. 21, No. 9, 2009, pp. 512-517.

[14]Egyptian Standards-Building Materials Committee, "Aggregates for concrete (ES 1109)," Egyptian Organization for Standards and Quality (EOS), Cairo. 2009.

[15] J. L. Poole, "Modeling temperature sensitivity and heat evolution of concrete," The University of Texas at Austin, 2007, pp. 216-241.

[16] K. A. Riding, J. L. Poole, A. K. Schindler, M. C. Juenger, and K. J. Folliard, "Evaluation of temperature prediction methods for mass concrete members," ACI Materials Journal, vol. 103, No. 5, 2006, pp. 357-365.

[17] S. Swaddiwudhipong, H.Wu, and M. H. Zhang, "Numerical simulation of temperature rise of highstrength concrete incorporating silica fume and superplasticiser," Advances in cement research, vol. 15, No. 4, 2003, pp. 161-169.

[18] J. Gajda, and M.Vangeem, "Controlling temperatures in mass concrete," Concrete international, vol. 24, No. 1, 2002, pp.58-62.

[19]P. Morabito, "Methods to determine the heat of hydration of concrete. Prevention of thermal cracking in concrete at early ages," RILEM Report, vol. 15, 1998, pp.1-25.

[20] ACI Committee 207, "Mass Concrete (ACI 207.1R96)," American Concrete Institute, Farmington Hills, Mich, 1996, pp. 29-37. 